\title{
SOEP
}

SOEPpapers

SOEPpapers
on Multidisciplinary Panel Data Research

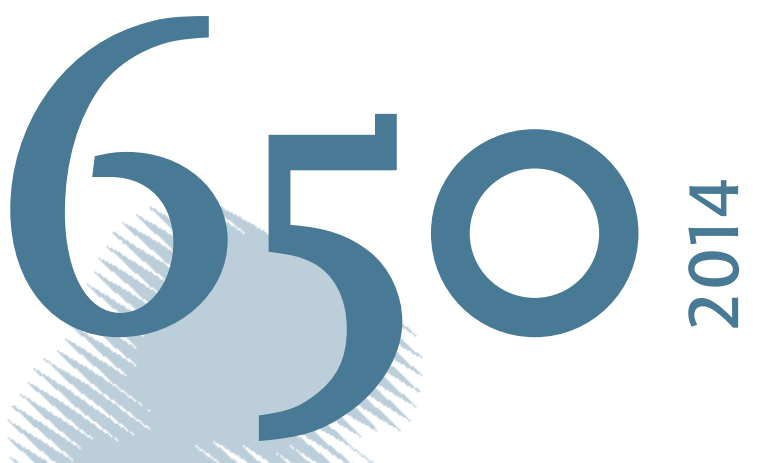

\section{The standard portfolio choice problem in Germany}

Steffen Huck, Tobias Schmidt and Georg Weizsäcker 


\section{SOEPpapers on Multidisciplinary Panel Data Research}

at DIW Berlin

This series presents research findings based either directly on data from the German SocioEconomic Panel Study (SOEP) or using SOEP data as part of an internationally comparable data set (e.g. CNEF, ECHP, LIS, LWS, CHER/PACO). SOEP is a truly multidisciplinary household panel study covering a wide range of social and behavioral sciences: economics, sociology, psychology, survey methodology, econometrics and applied statistics, educational science, political science, public health, behavioral genetics, demography, geography, and sport science.

The decision to publish a submission in SOEPpapers is made by a board of editors chosen by the DIW Berlin to represent the wide range of disciplines covered by SOEP. There is no external referee process and papers are either accepted or rejected without revision. Papers appear in this series as works in progress and may also appear elsewhere. They often represent preliminary studies and are circulated to encourage discussion. Citation of such a paper should account for its provisional character. A revised version may be requested from the author directly.

Any opinions expressed in this series are those of the author(s) and not those of DIW Berlin. Research disseminated by DIW Berlin may include views on public policy issues, but the institute itself takes no institutional policy positions.

The SOEPpapers are available at

http://www.diw.de/soeppapers

\section{Editors:}

Jürgen Schupp (Sociology)

Gert G. Wagner (Social Sciences, Vice Dean DIW Graduate Center)

Conchita D'Ambrosio (Public Economics)

Denis Gerstorf (Psychology, DIW Research Director)

Elke Holst (Gender Studies, DIW Research Director)

Frauke Kreuter (Survey Methodology, DIW Research Professor)

Martin Kroh (Political Science and Survey Methodology)

Frieder R. Lang (Psychology, DIW Research Professor)

Henning Lohmann (Sociology, DIW Research Professor)

Jörg-Peter Schräpler (Survey Methodology, DIW Research Professor)

Thomas Siedler (Empirical Economics)

C. Katharina Spieß (Empirical Economics and Educational Science)

ISSN: 1864-6689 (online)

German Socio-Economic Panel Study (SOEP)

DIW Berlin

Mohrenstrasse 58

10117 Berlin, Germany

Contact: Uta Rahmann | soeppapers@diw.de 


\title{
The standard portfolio choice problem in Germany*
}

\author{
Steffen Huck ${ }^{\dagger}$ \\ WZB Berlin and UCL
}

\author{
Tobias Schmidt $\ddagger$ \\ Humboldt University Berlin \\ and DIW Berlin
}

\author{
Georg Weizsäcker ${ }^{\S}$ \\ Humboldt University Berlin \\ and DIW Berlin
}

June 3, 2014

\begin{abstract}
We study behavior in an investment experiment conducted with a representative sample of German households (SOEP-IS). Respondents allocate a fixed budget between a safe asset and a risky asset whose returns are tied to the German stock market and earn monetary returns based on their decisions. Experimental investment choices correlate with beliefs about stock market returns and exhibit desirable external validity: They are a strong predictor for reallife stock market participation. The experimental set-up allows exogenous modification of the risky asset's return but investments are inelastic except for financially savvy subsamples. A laboratory experiment accompanies the data collection and yields similar results.
\end{abstract}

JEL classification: D1, D14, D84, G11

Keywords: Stock market expectations, stock market participation, portfolio choice, artefactual field experiment, $S O E P$

*We thank Tanika Chakraborty and seminar audiences at WZB Berlin for helpful comments. Furthermore, we thank Jürgen Schupp, David Richter, Elisabeth Liebau and Nico Siegel for their help and expertise in preparing and administering the SOEP-IS survey module and colleagues at the decision laboratory of Technical University Berlin for their excellent contributions in the preparation and conduct of the experiments. Financial support by the ERC (Starting Grant 263412) is gratefully acknowledged.

†WZB Berlin, Reichpietschufer 50, 10785 Berlin, steffen.huck@wzb.eu

‡DIW Berlin, Mohrenstr. 58, 10117 Berlin, tschmidt@diw.de

$\S$ Humboldt University Berlin, Spandauer Str. 1, 10178 Berlin, weizsaecker@hu-berlin.de 


\section{Introduction}

Low stock market participation rates remain among the most robust and most striking economic phenomena. In times of low bond returns the pattern gives fresh reason for concern in that not taking advantage of the equity premium jeopardizes the viability of many retirment plans. Policy makers may want to increase stock ownership and consider interventions trying to induce behavioral change. But how would one design and test such interventions?

In this study we present an artefactual field experiment that examines investment behavior in a representative sample of the German population. The simple choice-based experiment (i) produces results that correlate reliably with real-life investment decisions, (ii) can be implemented easily for a large number of people, and (iii) allows studying exogenous interventions. The experiment can thus serve as a wind tunnel for studying household investments in financial markets. Treating different subsamples of respondents with exogenous variations of asset returns we find that only financially savvy respondents react to changes in financial incentives.

We use households from the Innovation Sample of the German Socio-Economic Panel (SOEP-IS) as respondents. They act as investors who face a standard portfolio choice problem, allocating a fixed budget between a safe asset and a risky asset. No other investments are possible and asset returns realize after a fixed investment horizon. Despite its drastic simplifications, this model is widely viewed to capture one of the main tradeoffs in financial decision-making and is a good candidate for an empirical wind tunnel. We regard the extent to which the model captures actual behavior as an empirical question and examine both its internal consistency and external validity for Germany's general population. Regarding external validity, behavior in our artefactual investment task is robustly correlated with actual stock market participation even after controlling for many correlates the extant literature has identified. Regarding internal consistency, we find that the respondents' willingness to invest in the risky asset is correlated with measures of their beliefs in the stock market returns, lending further credibility to the story that the standard portfolio choice model tells. However, the behavioral reaction to an exogenous change in returns also shows how severely respondents' cognitive limitations and financial skills affect decisions. Only a subsample of financially savvy respondents reacts to changes in incentives. For all other respondents, the opportunity to earn additional money is lost.

Alongside the field experiment, we also present a complementary laboratory study in which we use the same protocol on a convenience sample of university students. The results are largely congruent between the two settings, with one notable difference. University students do react to the variation in incentives. But both, students and the representative SOEP-IS sample, do not consider the exogenous variation of returns adequately in their expectations. Beliefs react too weakly for all respondents.

In our choice task the respondents are asked to imagine investing $€ 50,000$ for a period of one year in either a safe asset that pays $4 \%$ or in a risky asset. Actual payments are scaled down by a factor of $1 / 2,000$, hence each respondent invests $€ 25$ of real money. The risky asset is constructed by drawing from historical returns on the DAX, Germany's prime blue chip stock market index. The DAX is well-known to German households at least by name due to vast media coverage. The risky asset's return differs between different experimental treatments. Depending on a respondent's treatment, the risky asset pays a year-on-year return of the DAX plus or minus 0, 5 or 10 percentage points. We elicit beliefs about the risky asset's return through two mechanisms, one that asks for the distribution of returns via a histogram elicitation method and one that asks only for the expected (average) return. We also elicit forward-looking expectations about the current year's DAX return. 
In order to assess external validity of the different reponse variables, we compare how strongly each of them is statistically associated with stock market participation. The investment in the experiment ("equity share" hereafter) shows a strong association with stock market participation. The unconditional stock market particpation rate is 18 percent in our representative sample of households and moving the experimental equity share by one standard deviation moves stock market participation by 6 percentage points. The estimates are equally large when controlling for other variables in multivariate regression analyses.

As alluded to above, the exogenous treatment variation has, overall, a surprisingly small effect. While the student population's investments significantly react to the manipulation of returns, the full set of representative households reacts only very weakly and not to a statistically significant extent. However, we do find treatment effects for relevant subgroups, namely those respondents with a university degree, those with relatively high wealth levels and those who display good numerical skills. But for no relevant subsample (not even the university students in the laboratory experiment) do beliefs react to the manipulation in the predicted way. The overall weak response to the treatment variation and the differential responses in different subsamples are consistent with the hypothesis that a only highly financially savvy people can form, modify, and ultimately react to beliefs in a rational way. We add the observations that our belief data offer a surprisingly precise description of historical returns and that they correlate strongly with the experimental equity share. It is thus implausible that the belief data are mere noise. We therefore interpret the results as an indication that while belief statements are straightforward, the manipulation of beliefs is especially difficult even for financially/numerically savvy respondents.

The observation that the belief data show a strong degree of realism is surprising. Even when considering the relatively difficult task of creating histograms, the aggregate belief across all households in the representative sample mirrors the actual (historical) return distribution almost perfectly. This is relevant because it lends support to the suspicion of Haliassos and Bertaut (1995) that at least in Germany low stock market participation is not simply caused by a systematic bias in the population's quantitative assessment of stock market returns.

In terms of possible interventions to increase stock market participation, one implication of our study is that policies that create incentives to invest may have different effects on different people. Even when controlling for important factors like availability of investment opportunities, the less financially savvy may react less to incentive schemes that are put in place, potentially causing unintended distributional effects.

Relation to existing literature. Our experimental design builds on sizable literatures on stock market participation, belief elicitation and experiments on choice under uncertainty. Our results are not in all cases consistent with these literatures and we emphasize some of the relevant comparisons. Yet the gist of our findings - evidence of the importance of task complexity and cognitive ability - is consistent with the previous literature.

The observation that stock market participation is puzzlingly low is widely credited to Haliassos and Bertaut (1995) who find that not only do relatively few members of the middle class invest in stocks, but even amongst the rich, where classical rationales for non-participation are unlikely to hold, participation is far from universal. Germany is a strong case for this puzzle, as only about $18 \%$ of households are stockholders. To investigate the stock market participation puzzle, "behavioral" explanations are common in the literature ${ }^{1}$ and observational or experimental findings

\footnotetext{
${ }^{1}$ Frequently mentioned explanations are education, cognitive skills (Grinblatt, Keloharju, \& Linnainmaa, 2011) and financial literacy (van Rooij, Lusardi, \& Alessie, 2007), transaction cost and availability of information.
} 
on financial literacy and subjective expectations abound (for survey evidence on financial literacy and its correlates in the German population, see Bucher-Koenen and Lusardi (2011)).

There has been considerable interest in recent years in measuring the subjective beliefs of the general public about stock returns and to understand how elicited beliefs correlate with real-life investments. The earliest survey questions about stock-market expectations ask for a measure of central tendency only (Vissing-Jorgensen, 2004). Probabilistic beliefs were first elicited in the 2002 version of the Health and Retirement Survey in which respondents were asked for the "chance that mutual fund shares invested in blue chip stocks like those in the Dow Jones Industrial Average will be worth more than they are today" and the "chance they will have grown by 10 percent or more" (Dominitz \& Manski, 2007). Ideally these two question yield two points on the CDF and, if one is willing to make distributional assumptions, allow fitting an entire distribution for every individual. The method has since been generalized to more than two points. Dominitz and Manski (2011) analyse data from 27 monthly waves of the Survey of Economic Expectations from July 1999 to March 2001 and three waves of the Michigan Survey of Consumers from 2002 to 2004 in which respondents were asked a series of questions about the probability of a hypothetical investment in stocks exceeding a certain threshold. Arrondel, Calvo-Pardo, and Tas (2012) ask questions with a similar format.

One drawback of these methods is that responses are often internally inconsistent. In the HRS data 41 percent of respondents give the same answer to both, the question about the likelihood of a positive return and the question about a return above $10 \%$, and a further 15 percent violate monotonicity outright (Binswanger \& Salm, 2013) indicating the intrinsic difficulty of belief formation tasks.

Instead of asking for probabilities of a return lying above a threshold, we use a histogram elicitation method pioneered by Delavande and Rohwedder (2008) in which respondents are asked to distribute a fixed number of items that jointly represent a probability mass of 1 into a number of bins. The method allows using all available data instead of focussing on consistent sets of responses. The method also has the advantage of being easy for respondents to understand; it is robust to several variations and has been successfully used even with respondents with little formal education and low numerical and statistical skills (Delavande, Giné, \& McKenzie, 2011).

The broad picture emerging from this literature is that expectations (and their adaptions) are extremely heterogeneous and often far off actual returns (M. Hurd, Rooij, \& Winter, 2011). For example, Kézdi and Willis (2009) find that in 2002 the average subjective probability of a stock market gain was just $49 \%$ compared to a historical probability of $73 \%$. Dominitz and Manski (2011) report that from 2002 to 2004, the average subjective probability of a gain was $46.4 \%$. This is in stark contrast to our finding that aggregate beliefs accurately capture the historical return distribution. There are, of course, many possible reasons why belief accuracy may change between points in time and between countries.

Questions to elicit the entire subjective distribution of market returns have recently been added to the Survey of Economic Expectations (Dominitz \& Manski, 2011), the Michigan Survey of Consumers (Dominitz \& Manski, 2011), the American Life Panel (M. D. Hurd \& Rohwedder, 2012), the French 'Mode de vie des Français' panel (Arrondel et al., 2012) and the Dutch CentER panel (M. Hurd et al., 2011). These studies all report on the positive predictive power of elicited beliefs. In our data elicited beliefs have much less predictive power for stock market participation. This may in part be due to the smaller sample size (we have 562 representative households, whereas the cited papers all have a few thousand) yielding estimates with wider confidence intervals. But there is further evidence suggestive of a systematic difference between the German sample and others. 
The subjective probability of the relevant stock market index making a gain varies significantly less between stockholders and non-stockholders in our data than in does in the other studies. ${ }^{2}$

While there is an enormously large literature on how people make risky choices (with several recent advances on choice patterns in representative samples, see, for example, Andersen, Harrison, Lau, and Rutström (2008), Rabin and Weizsäcker (2009), von Gaudecker, van Soest, and Wengström (2011), Huck and Müller (2012) or Choi, Kariv, Müller, and Silverman (2013)) and an equally large literature on how socio-economic characteristics correlate with stock market participation ${ }^{3}$, there are no existing studies that we know of that examine whether risky choices in simple lab-style portfolio problems help to predict stock holdings. While our finding of a strong correlation between an experimental investment and real-life stock market participation is new, the idea is not. In the working paper version of Dohmen et al. (2011) the authors report on an investment experiment that was done in a German household survey and is not too different from ours. Their data, however, are much more clustered at the boundary of the response space $(60 \%)$ and were generated without monetary incentives for the investment and without accompanying belief elicitation. Dohmen et al. make the important observation that domain-specific risk attitudes are better predictors of realworld behaviors. This is consistent with our finding that a choice framed in the context of financial markets is a better predictor for real-life stock holdings than, for example, the repsondents' general risk tolerance.

Finally, we observe that given the lack of response to strongly varying incentives that we observe in our study, it is perhaps not surprising that elsewhere investors are found to react to extraneous information such as advertisements for standard financial assets (like individual stocks) or photos of financial advisors (Bertrand, Karlan, Mullainathan, Shafir, \& Zinman, 2010). This is also consistent with the findings of Binswanger and Salm (2013) who re-investigate the HRS data and argue that large subsamples of the population may not think probabilistically about stock market investments.

The remainder of the paper is organized as follows. In Section 2 we describe the experimental design and procedures both for the household panel and the laboratory. In Section 3 we focus on the experimental data, analyze treatment effects and study the relation between beliefs about returns and investments in the experiment. In Section 4 we turn to the validity questions that relate the experimental data to socioeconomic data from the household panel. Section 5 discusses the differential results that we find for different subsamples of our data and Section 6 concludes.

\section{Experimental Design and Procedures}

\subsection{Survey module}

Our experimental module was part of the 2012 wave of the German Socioeconomic Panel's Innovation Sample (SOEP-IS, see Richter \& Schupp, 2012, for details). The SOEP is a nationally representative sample of the German population and the SOEP-IS is its sister survey which is used to trial new questions and modules. Its sampling of households follows the same procedure as the SOEP and renders the SOEP-IS representative of the German population. The module was presented to 1146 respondents in 700 households, all of which were new members of the SOEP-IS in

\footnotetext{
${ }^{2}$ In each of M. Hurd et al. (2011), Dominitz and Manski (2011) and Arrondel et al. (2012), the stockholders assign about ten percentage points more probability mass to the event that the relevant index makes a gain. In our data, this probability differs between stockholder and non-stockholders only by 2.3 percentage points.

${ }^{3}$ Guiso, Sapienza, and Zingales (2008) show with Dutch household panel data how general trust correlates with stock holdings.
} 
2012. All households completed the long baseline questionnaire on the same day as our experimental module. Trained interviewers collected responses via computer-aided personal interviewing (CAPI) at the respondents' homes. In the data analysis, we will only use the responses of one person per household, namely those given by the person who also responds to the baseline questionnaire.

The module contains a regular survey component that we use to elicit several aspects of respondents' asset portfolio (liquid assets, debt, retirement savings) as well as financial literacy and attitudes towards savings and risk. The core component of the module is the interactive experiment ${ }^{4}$ modelled on the standard portfolio choice problem that we describbe in the following.

The first screen of our experiment confronts respondents with a summary description of the investment decision. They are asked to imagine owning $€ 50,000$ which they invest for the duration of one year. The two available assets are a safe asset that pays $4 \%$ and a risky asset, referred to as the "fund", which is based on the DAX, Germany's prime blue chip stock market index. Respondents receive a one-sentence description of the DAX and learn that depending on the treatment the fund pays a return equal to a DAX return drawn from a historic distribution plus a percentage point shifter. There are five treatments that differ in the shifter value, with possible values in the set $\{-10,-5,0,5,10\}$. Respondents are randomly allocated to treatments. If their shifter value is 0 , then the shifter is not mentioned (for simplicity). Otherwise the first screen indicates the absolute size of the shifter but not its sign. For example, a respondent would learn that the fund pays either 5 percentage points less than the DAX or 5 percentage points more than the DAX and that she will subsequently learn which of the two values applies. The respondents also learn that they will be paid in cash on a smaller scale at the end of the survey.

On the second screen, they receive more detailed explanations about the determination of payments including (in bold letters) the information of the shifter's sign that "the computer has now randomly drawn". We use this two-step revelation of the shifter's random draw in order to maximize the respondent's appreciation that the shifter is random with zero mean, carrying no information about the underlying DAX return. Since each respondent learns only one realized shifter value, our highlighting of the mirrored value may make the shifter's uninformativeness more salient. The procedure also ensures that the instructions of the laboratory replication are identical despite the fact that only two shifter values are possible there (see below).

The text on the second screen also gives some numerical examples and specifies that the fund's return depends on a draw from historical DAX returns from 1951 to 2010 and that actual payments are scaled down by a factor of $2000 .^{5}$

Upon reading these short instructions the respondents make their investment decision on the third screen. Respondents who invest their entire endowment in the riskless asset would receive a certain payment of $€ 26$. Investing the entirety in the risky asset would yield a payment anywhere from $€ 11.52$ and $€ 56.52$ depending on treatment and the randomly drawn year. No information on historical returns is made available to the respondents during the experiment. Under the assumptions of rational expectations, EU-CRRA and usual degrees of risk aversion, one can generate the approximate prediction that in treatments with non-negative shifters, most respondents should invest their entire endowment (all respondents with degree of relative risk aversion below 3); those

\footnotetext{
${ }^{4}$ To minimize interviewer influence, the CAPI-notebooks are placed in front of the respondents and they themselves get to enter their responses. The interviewers are instructed to intervene only if respondents show visible difficulties with the task or explicitly ask for help.

${ }^{5}$ For all years since the DAX's origination in 1988 we use the actual yearly returns on the index. For all previous years we make use of the yearly return series from Stehle, Huber, and Maier (1996) and Stehle, Wulff, and Richter (1999), who impute the index going back all the way to 1948. All returns are nominal. In contrast to e.g. the S\&P 500 the DAX is a performance index, which means that dividend payments are included in the return calculations.
} 
with a shifter of -10 should invest very little whereas those with -5 should invest intermediate amounts. ${ }^{6}$

On the fourth screen we elicit respondents' beliefs about the return of the fund, using the histogram elicitation method pioneered by Delavande and Rohwedder (2008) and refined by Delavande et al. (2011) and Rothschild (2012). ${ }^{7}$ A screenshot of the interface can be found in Appendix A. Respondents have to place 20 "bricks", each representing a probability mass of $5 \%$, into seven bins of possible percentage-point returns. The set of available bins is $\{(-90,-60),(-60,-$ $30),(-30,0),(0,30),(30,60),(60,90),(90,120)\}$. The bins are, hence, wide enough to render responses covering the enitre support of the historical return distribution meaningful ${ }^{8}$ and more generally to allow for a wide set of possible subjective beliefs. In addition, on the fifth screen, respondents enter their "expectation of the average" return of the fund. For both the histogram elicitation of beliefs and for the stated beliefs, it is straightforward to fomulate the rational prediction of treatment differences: no matter what the distribution of beliefs in the population, the shifter should move the beliefs one-to-one. For example, the reported beliefs should differ by 20 percentage points between the -10 shifter and the +10 shifter.

Like all previous surveys on beliefs about stock market returns we decided not to incentivize either of these belief measures. Proper incentivizing of the belief elicitation would have required a complicated mechanism whose explanation would have severely strained the attention span of our respondents. ${ }^{9}$

On the sixth and seventh screens, respondents report how confident they are of their belief statements, on a scale from 0 ("not at all") to 10 ("very sure"), and answer a few understanding questions. The eighth screen elicits the respondents' beliefs about next year's DAX return using the same histogram interface that was used before. Finally, on the ninth and last screen of the experimental module respondents were told which of the years between 1951 and 2010 had been drawn and received a detailed calculation for their payment. Respondents were paid in cash, with amounts rounded up to the nearest euro, at the end of the entire survey interview. On average respondents received $€ 27.16$ (min: $€ 17$, s.d.: $€ 3.43$, max: $€ 48$ ).

\footnotetext{
${ }^{6}$ These statements hold in a classic two-period two-asset portfolio choice model with log-normal asset returns and CRRA utility over wealth in the second period (i.e. a simplified version of Merton (1969) and Samuelson (1969); see also Campbell and Viceira (2002)). The optimal equity share $\alpha$ can be approximated by:

$$
\alpha=\frac{\mu_{r}-r_{f}+\sigma_{r}^{2} / 2}{\rho \cdot \sigma_{r}^{2}}
$$

where $\mu_{r}$ is the expected $\log$ return, $\sigma_{r}^{2}$ is the variance of returns, $r_{f}$ is the logarithm of the risk-free rate and $\rho$ is the coefficient of relative risk aversion. Over the payoff-relevant period 1951-2010 the log-normality assumption was approximately correct for year-on-year returns on the DAX (Shapiro test p-value: 0.6), the mean log-return was 0.11 and the variance of returns was 0.1 . The riskless asset in the experiment paid $4 \%$. The predictions made in the main text readily result under rational expectations. For respondents with log-utility $(\rho \approx 1)$ the optimal equity share in Treatment 0 is 1 , in Treatment -5 it is 0.74 and in Treatment -10 it is 0.22 . Under the same assumptions positive shifters have no effect on equity share, which remains at the corner solution. However, given that equity shares observed in reality are often much lower than those predicted by the model and that most of the finance literature estimates risk aversion to be substantially higher we decided to also include positive shifters.

${ }^{7}$ For an overview of studies which have used this or similar methods see Goldstein and Rothschild (2014) and references therein.

${ }^{8}$ The lowest return on the DAX in the payoff-relevant period was $-43.9 \%$ in 2002 . The highest return was $116.1 \%$ in 1951.

${ }^{9}$ Systematic experimental evidence provided by Armantier and Treich (2013) and Trautmann and van de Kuilen (2011) shows that the wrong scoring rule can induce bias in the responses. In contrast, not incentivising the elicitation of beliefs does not yield biased answers in these studies but merely noisier answers. A further concern with incentives is the introdction of possible motives for attempted hedging between tasks (see e.g. Karni \& Safra, 1995).
} 


\begin{tabular}{lc}
\hline & Dependent variable: Participation in the Experiment \\
\hline Female & $-0.003(0.030)$ \\
Born in the GDR & $0.028(0.038)$ \\
Abitur & $0.043(0.058)$ \\
University Degree & $0.002(0.070)$ \\
Household Size & $-0.018(0.019)$ \\
Number of Children in Household & $0.020(0.034)$ \\
Employed & $0.016(0.038)$ \\
Financially Literate & $0.027(0.030)$ \\
Interest: $<$ 250 Euros & $-0.027(0.035)$ \\
Interest: 250 - 1.000 Euros & $0.026(0.049)$ \\
Interest: 1.000 - 2.500 Euros & $0.098(0.093)$ \\
Interest: $>2.500$ Euros & $0.120(0.250)$ \\
Interest: refused to answer & $-0.074(0.087)$ \\
Stock Market Participant & $0.028(0.047)$ \\
Risk Tolerance: Low & $0.030(0.033)$ \\
Risk Tolerance: High & $0.028(0.041)$ \\
Age bracket 31-40 & $0.032(0.077)$ \\
Age bracket 41-50 & $-0.082(0.059)$ \\
Age bracket $51-60$ & $-0.084(0.057)$ \\
Age bracket $61-70$ & $-0.064(0.060)$ \\
Age bracket 71-80 & $-0.190^{* * *}(0.060)$ \\
Age bracket $>80$ & $-0.260^{* *}(0.110)$ \\
N & 692 \\
Log Likelihood & -316.000 \\
AIC & 678.000 \\
\hline
\end{tabular}

${ }^{*} \mathrm{p}<.1 ;{ }^{* *} \mathrm{p}<.05 ;{ }^{* * *} \mathrm{p}<.01$

Standard errors are bootstrapped with 1000 replicates

Table 1: Selection into the experiment: Probit marginal effects

The participation rate in our experiment is $80 \%$. Those who decline to participate primarily cite old age and problems in using the computer interface but also lack of interest in financial matters as well as ethical and religious reservations against any sort of financial dealings. The Probit regressions shown in Table 1 mirror the answers to the open-ended question about the reasons for non-participation. The most potent predictor, indeed the only predictor, of selection into the experiment is age. Respondents over the age of 40 are somewhat less likely to participate and respondents above the age of 70 are significantly less likely to participate. Their participation rate is about two thirds. ${ }^{10}$ All other observable characteristics play no role in the selection into the experiment. A Wald-test for the joint sigificance of all variables other than the age brackets cannot reject the null of no effect $\left(\chi^{2}(18)=19.54, p=0.36\right)$.

\footnotetext{
${ }^{10}$ There are about 120 main household repondents above age 70 in the sample, hence the increase in nonparticipation among the elderly amounts to only about 15 sets of observations.
} 


\subsection{Laboratory Experiment}

Upon completion of the field data collection in the SOEP-IS, we used the identical experimental module for a set of 198 university students in the WZB-TU Berlin decision laboratory in 2012/13. Recruitment into the laboratory sample followed standard procedures. ${ }^{11}$ The instructions and sequence of informational display on the computer screens in the laboratory are as close to the CAPI environment as we could produce them such that potential practical difficulties with the format would affect both populations. The experimental participants' payments were also scaled by the same factor as payments to SOEP participants. The only relevant difference in experimental design and procedures are that (i) the experimental participants do not have to fill out the long SOEP questionnaire, and (ii) we conducted only the two treatments -10 and 10 in the laboratory, presenting the strongest treatment difference in incentives. Since the SOEP respondents who happened to be in either of these two treatments were only informed about the existence of these two treatments, we could leave the instructions entirely unchanged between survey and lab environments.

\section{Experimental Data}

The data analysis commences by considering the experimental variables collected in both the SOEP sample and the laboratory sample. Sections 4 and 5 focus on the SOEP sample and consider the experimental variables' relation with stock market participation and other personal background variables.

Subsection 3.1 describes the correlation between equity share (the investment in the risky asset) and beliefs. Subsection 3.2 addresses the connection between these two variables and the shifter variable from the experimental treatments. Since the shifter is exogenous, its correlation with other variables indicates causality. Subsection 3.3 addresses the accuracy of beliefs relative to the historical return distribution.

\subsection{Beliefs and Investments}

We start by a summary description of equity shares and elicited beliefs about the fund's return. In both samples the distribution of equity shares has a relatively large support and is not too lumpy, giving rise to the possibility of finding co-variation with other variables. Summing over all treatments, the means (and standard deviations in parentheses) of the equity share are $0.37(0.25)$ in the SOEP sample and $0.46(0.31)$ in the laboratory sample. The proportions of respondents investing all, exactly half, or nothing in the risky asset are 0.03, 0.2 and 0.18 in the SOEP sample and $0.12,0.05$ and 0.09 in the laboratory sample.

A description of the beliefs about the fund's return is more involved, since each belief report contains an entire histogram. A clear difference between the SOEP and the lab is that the laboratory participants use more bins than the representative respondents. ${ }^{12}$ The median numbers of bins that contain at least one brick is 6 in the laboratory while it is only 3 in the SOEP where $28 \%$ of respondents use only a single bin and a further $14 \%$ only use two bins. Compared with other belief elicitations using similar methods these frequencies are on the low side. Delavande and Rohwedder (2008) report that $73 \%$ of their subjects used two bins or less.

${ }^{11}$ The decison laboratory uses ORSEE (Greiner, 2004).

${ }^{12}$ Appendix $\mathrm{C}$ contains examples of the raw data of elicited histograms from both samples. 


\begin{tabular}{|c|c|c|c|c|c|c|c|c|}
\hline & \multicolumn{2}{|c|}{ Equity Share } & \multicolumn{2}{|c|}{$\begin{array}{c}\text { Imputed } \\
\text { Expectation of } \\
\text { Belief }\end{array}$} & \multicolumn{2}{|c|}{$\begin{array}{c}\text { Imputed S.D. of } \\
\text { Belief }\end{array}$} & \multicolumn{2}{|c|}{$\begin{array}{c}\text { Stated } \\
\text { Expectation of } \\
\text { Belief }\end{array}$} \\
\hline & Mean & S.D & Mean & S.D & Mean & S.D & Mean & S.D \\
\hline Overall & 0.37 & $(0.25)$ & 12.53 & $(20.59)$ & 23.96 & $(16.54)$ & 8.27 & $(17.84)$ \\
\hline \multicolumn{9}{|l|}{ Age Bracket } \\
\hline$<30$ & 0.41 & $(0.27)$ & 12.16 & $(16.06)$ & 30.25 & $(16.07)$ & 8.74 & $(16.64)$ \\
\hline $31-40$ & 0.39 & $(0.22)$ & 13.85 & $(15.73)$ & 25.60 & $(17.13)$ & 12.02 & $(16.54)$ \\
\hline $41-50$ & 0.40 & $(0.23)$ & 12.57 & $(24.70)$ & 26.36 & $(16.75)$ & 7.12 & $(18.65)$ \\
\hline $51-60$ & 0.37 & $(0.26)$ & 13.24 & $(21.86)$ & 22.72 & $(16.46)$ & 8.43 & (19.41) \\
\hline $61-70$ & 0.34 & $(0.26)$ & 10.02 & (19.63) & 20.46 & $(15.88)$ & 6.22 & $(17.27)$ \\
\hline $71-80$ & 0.31 & $(0.26)$ & 14.93 & $(23.28)$ & 19.89 & $(15.42)$ & 9.77 & $(17.19)$ \\
\hline$>80$ & 0.43 & $(0.37)$ & 8.55 & (15.81) & 14.39 & $(7.97)$ & -1.40 & $(18.39)$ \\
\hline \multicolumn{9}{|l|}{ Gender } \\
\hline $\begin{array}{l}\text { female } \\
\text { male }\end{array}$ & $\begin{array}{l}0.35 \\
0.39\end{array}$ & $\begin{array}{l}(0.24) \\
(0.26)\end{array}$ & $\begin{array}{c}9.72 \\
15.14\end{array}$ & $\begin{array}{l}(22.29) \\
(18.52)\end{array}$ & $\begin{array}{l}25.60 \\
22.43\end{array}$ & $\begin{array}{l}(17.20) \\
(15.78)\end{array}$ & $\begin{array}{l}7.86 \\
8.65\end{array}$ & $\begin{array}{l}(21.59) \\
(13.46)\end{array}$ \\
\hline \multicolumn{9}{|l|}{ Born in } \\
\hline West Germany & 0.37 & $(0.26)$ & 12.11 & $(20.97)$ & 23.34 & $(15.60)$ & 7.40 & $(17.38)$ \\
\hline East Germany & 0.34 & $(0.23)$ & 12.87 & $(21.96)$ & 22.47 & $(17.46)$ & 7.75 & $(17.69)$ \\
\hline abroad & 0.42 & $(0.28)$ & 14.95 & (15.44) & 29.74 & $(19.10)$ & 14.66 & $(17.35)$ \\
\hline \multicolumn{9}{|l|}{ Abitur } \\
\hline no & 0.37 & $(0.25)$ & 13.02 & $(20.87)$ & 23.20 & $(16.93)$ & 8.78 & $(18.85)$ \\
\hline yes & 0.37 & $(0.28)$ & 10.74 & (19.51) & 26.70 & $(14.83)$ & 6.40 & (13.47) \\
\hline \multicolumn{9}{|l|}{ University Education } \\
\hline & 0.37 & $(0.25)$ & 12.67 & $(20.42)$ & 23.52 & $(16.67)$ & 8.67 & $(18.01)$ \\
\hline yes & 0.35 & $(0.28)$ & 11.54 & $(21.78)$ & 26.95 & $(15.40)$ & 5.55 & $(16.46)$ \\
\hline \multicolumn{9}{|l|}{ Employed } \\
\hline no & 0.35 & $(0.26)$ & 11.27 & $(20.42)$ & 23.49 & $(17.01)$ & 7.47 & $(19.58)$ \\
\hline yes & 0.39 & $(0.25)$ & 13.64 & $(20.70)$ & 24.38 & $(16.13)$ & 8.98 & $(16.13)$ \\
\hline \multicolumn{9}{|l|}{ Financially Literate } \\
\hline no & 0.38 & $(0.26)$ & 11.05 & $(20.27)$ & 24.00 & $(17.14)$ & 8.47 & $(18.09)$ \\
\hline yes & 0.36 & $(0.25)$ & 14.13 & $(20.80)$ & 24.02 & $(15.98)$ & 8.08 & $(17.68)$ \\
\hline \multicolumn{9}{|l|}{ Stock Owner } \\
\hline no & 0.35 & $(0.24)$ & 12.50 & $(21.13)$ & 24.29 & $(16.99)$ & 8.11 & $(18.69)$ \\
\hline yes & 0.45 & $(0.29)$ & 12.79 & $(18.20)$ & 22.66 & $(14.55)$ & 8.95 & $(13.82)$ \\
\hline
\end{tabular}

Table 2: Experimental Responses in the SOEP by Subgroup

In the analysis below we will often use summary statistics of the reported belief distributions. To compute statistics like the expectation or the standard deviation of the belief distribution we take the 8 points on the CDF, interpolate between them using a cubic spline and then calculate the statistics numerically. A more detailed description of the interpolation procedure can be found in Appendix D.

Using these imputed distributions, we find that the average of the SOEP respondents' mean belief about the fund is 12.5 and the average of the respondents' standard deviation of the fund is 
24.0. For the laboratory sample, the average mean belief about the fund is 11.6 and the average standard deviation is 35.6.

As indicated in Section 2, we also elicited scalar belief reports by asking for the average expectation regarding the fund return. In the SOEP sample, this variable has a mean of 8.3 and a standard deviation of 17.8. In the laboratory sample, the mean of means is 11.0 and the standard deviation is 19.1. Moreover, stated expectations are highly correlated with expectations inferred from belief distributions in both settings (Spearman rank-correlation: 0.43 for the SOEP and 0.47 for the lab sample). Table 2 also collects all key descriptives for different subgroups of the SOEP sample.

We now investigate the extent to which equity share and beliefs are correlated. Figure 1 contains a scatter plot of equity shares and the belief measures for both the SOEP and the lab sample. While it shows both signs of regularity and irregularity, there is a pronounced positive relation between beliefs and investments overall. At the mean of the data an increase in the expected return by one percentage point is associated with a one third percentage point incrase in the equity share (see Figure 1 for OLS regressions). This relationship holds for both our belief measures and is roughly the same in the laboratory. The evidence on a positive statistical connection between beliefs and investments is consistent with many studies in the belief elicitation literature (see, for example, Naef and Schupp (2009) in the context of trust games).

Notice, however, that there are also patterns that are hard to square with the theoretical predictions of the standard model. As in Merkle and Weber (2014) there is a substantial fraction of subjects who expect a negative excess return for the experimental asset and yet invest positive amounts. 
SOEP
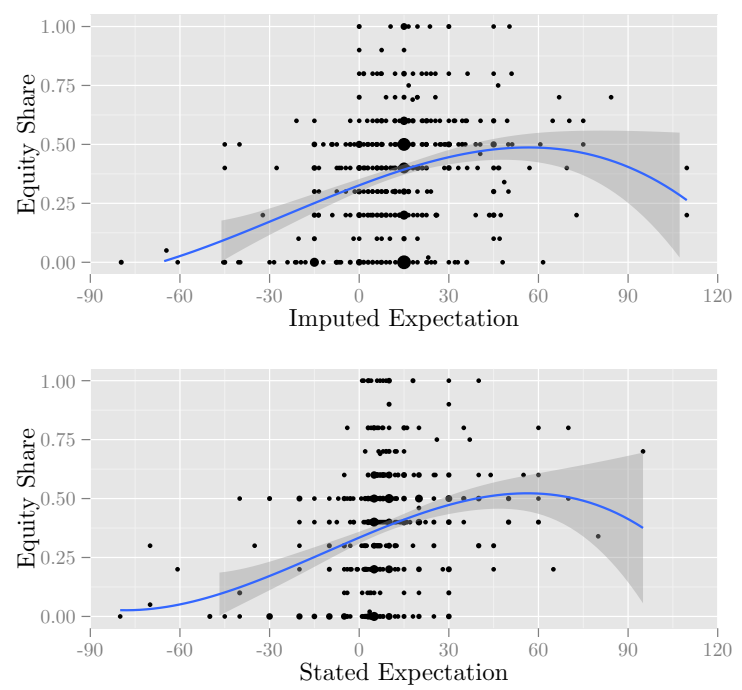

Lab
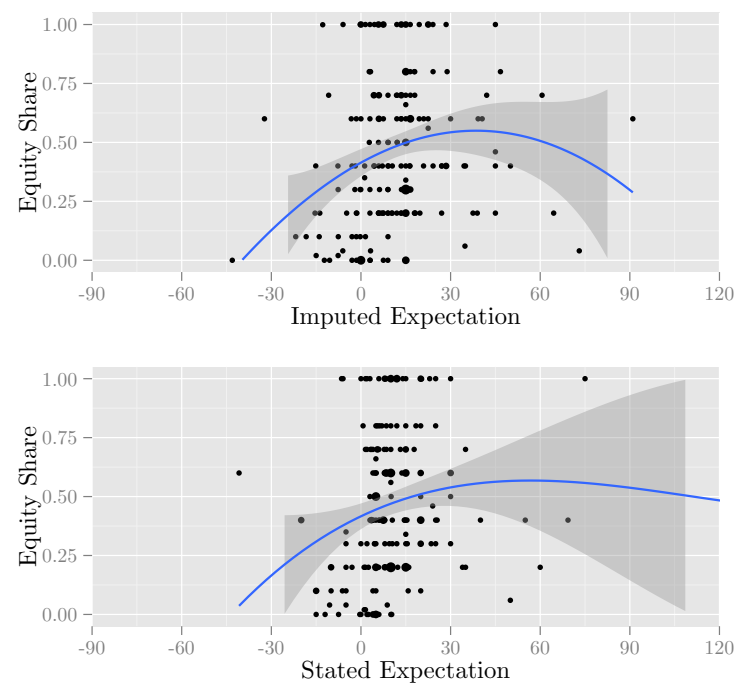

Overlapping observations are aggregated, with the dot's size being proportional to the number of observations thus aggregated. Model fit comes from a polynomial regression in which investments are a cubic function of expected return (Models 2, 5, 8 and 10 below).

\begin{tabular}{|c|c|c|c|c|c|c|c|c|c|c|}
\hline & \multicolumn{3}{|c|}{ SOEP: Stated Beliefs } & \multicolumn{3}{|c|}{$\begin{array}{l}\text { Dependent Variable: Equity Share } \\
\text { SOEP: Imputed Beliefs }\end{array}$} & \multicolumn{2}{|c|}{ Lab: Stated Beliefs } & \multicolumn{2}{|c|}{ Lab: Imputed Beliefs } \\
\hline & $(1)$ & $(2)$ & $(3)$ & (4) & $(5)$ & $(6)$ & $(7)$ & (8) & (9) & $(10)$ \\
\hline Imputed Expected Return & $\begin{array}{l}0.003^{* * *} \\
(0.0005)\end{array}$ & $\begin{array}{c}0.005^{* * *} \\
(0.001)\end{array}$ & $\begin{array}{c}0.005^{* * *} \\
(0.001)\end{array}$ & & & & $\begin{array}{l}0.003^{* *} \\
(0.001)\end{array}$ & $\begin{array}{c}0.007^{* * *} \\
(0.003)\end{array}$ & & \\
\hline Imputed Expected Return ${ }^{2}$ & & $\begin{array}{l}-0.00002^{* * *} \\
(0.00001)\end{array}$ & $\begin{array}{l}-0.00001 \\
(0.00001)\end{array}$ & & & & & $\begin{array}{l}-0.0001 \\
(0.0001)\end{array}$ & & \\
\hline Imputed Expected Return ${ }^{3}$ & & $\begin{array}{l}-0.00000^{* *} \\
(0.00000)\end{array}$ & $\begin{array}{l}-0.00000^{* * *} \\
(0.00000)\end{array}$ & & & & & $\begin{array}{l}-0.00000 \\
(0.00000)\end{array}$ & & \\
\hline Imputed S.D. of Return & & & $\begin{array}{c}0.001 \\
(0.001)\end{array}$ & & & & & & & \\
\hline Probability of a Gain & & & $\begin{array}{l}-0.010 \\
(0.037)\end{array}$ & & & & & & & \\
\hline Stated Expected Return & & & & $\begin{array}{l}0.004^{* * *} \\
(0.0005)\end{array}$ & $\begin{array}{c}0.005^{* * *} \\
(0.001)\end{array}$ & $\begin{array}{c}0.005^{* * *} \\
(0.001)\end{array}$ & & & $\begin{array}{c}0.002 \\
(0.002)\end{array}$ & $\begin{array}{c}0.006 \\
(0.005)\end{array}$ \\
\hline Stated Expected Return ${ }^{2}$ & & & & & $\begin{array}{l}-0.00001 \\
(0.00001)\end{array}$ & $\begin{array}{l}-0.00001 \\
(0.00001)\end{array}$ & & & & $\begin{array}{l}-0.0001 \\
(0.0002)\end{array}$ \\
\hline Stated Expected Return ${ }^{3}$ & & & & & $\begin{array}{l}-0.00000 \\
(0.00000)\end{array}$ & $\begin{array}{l}-0.00000 \\
(0.00000)\end{array}$ & & & & $\begin{array}{c}0.00000 \\
(0.00000)\end{array}$ \\
\hline Constant & $\begin{array}{c}0.330^{* * *} \\
(0.012)\end{array}$ & $\begin{array}{c}0.330^{* * *} \\
(0.013)\end{array}$ & $\begin{array}{c}0.370^{* * *} \\
(0.110)\end{array}$ & $\begin{array}{c}0.340^{* * *} \\
(0.011)\end{array}$ & $\begin{array}{c}0.330^{* * *} \\
(0.013)\end{array}$ & $\begin{array}{c}0.400^{* * *} \\
(0.110)\end{array}$ & $\begin{array}{c}0.420^{* * *} \\
(0.028)\end{array}$ & $\begin{array}{c}0.410^{* * *} \\
(0.035)\end{array}$ & $\begin{array}{c}0.440^{* * *} \\
(0.030)\end{array}$ & $\begin{array}{c}0.420^{* * *} \\
(0.037)\end{array}$ \\
\hline Personal Controls & No & No & Yes & No & No & Yes & No & No & No & No \\
\hline $\mathrm{N}$ & 562 & 562 & 560 & 562 & 562 & 560 & 198 & 198 & 198 & 198 \\
\hline $\mathrm{R}^{2}$ & 0.074 & 0.093 & 0.160 & 0.081 & 0.090 & 0.140 & 0.031 & 0.063 & 0.016 & 0.038 \\
\hline Adjusted $\mathrm{R}^{2}$ & 0.072 & 0.088 & 0.120 & 0.080 & 0.085 & 0.100 & 0.026 & 0.048 & 0.011 & 0.023 \\
\hline
\end{tabular}

Figure 1: Equity Share and Beliefs 


\subsection{Treatment effects}

\begin{tabular}{|c|c|c|c|c|c|c|c|c|}
\hline Setting & Variable & -10 & -5 & 0 & 5 & 10 & ANOVA & Kruskall-Wallis \\
\hline \multirow[t]{4}{*}{ SOEP } & Equity Share & $0.40(0.02)$ & $0.34(0.02)$ & $0.32(0.02)$ & $0.39(0.02)$ & $0.39(0.02)$ & 0.106 & 0.135 \\
\hline & Imputed Beliefs & $13.14(1.97)$ & $10.58(1.81)$ & $9.38(1.85)$ & $14.48(1.83)$ & $14.45(2.18)$ & 0.232 & 0.326 \\
\hline & Stated Beliefs & $8.55(1.71)$ & $7.68(1.70)$ & $6.60(1.98)$ & $9.28(1.43)$ & $8.93(1.66)$ & 0.810 & 0.990 \\
\hline & Probability of a Gain & $0.68(0.03)$ & $0.67(0.03)$ & $0.67(0.03)$ & $0.74(0.02)$ & $0.69(0.03)$ & 0.323 & 0.313 \\
\hline \multirow[t]{4}{*}{ Lab } & Equity Share & $0.30(0.03)$ & & & & $0.63(0.03)$ & 0.000 & 0.000 \\
\hline & Imputed Beliefs & $10.05(1.71)$ & & & & $13.37(1.57)$ & 0.156 & 0.016 \\
\hline & Stated Beliefs & $9.87(2.28)$ & & & & $12.30(1.38)$ & 0.374 & 0.004 \\
\hline & Probability of a Gain & $0.59(0.02)$ & & & & $0.65(0.01)$ & 0.029 & 0.009 \\
\hline
\end{tabular}

Table 3: Mean levels by treatment

Recall that we implement five exogenous treatments shifting the fund's return. The shifts are sizeable, ranging from -10 percentage points to +10 percentage points. Table 3 documents that by and large there is, surprisingly, no effect of the return shifter on equity share in the SOEP sample. The lack of response can hardly be explained by small incentives. In terms of the nominal framing of the $€ 50,000$ investment, the difference in returns between Treatments -10 and 10 amounts to a difference in gross returns of up to $€ 10,000$. In terms of the real monetary value of the experimental investment, the variation in return amounts to a difference of up to $€ 5$. Even the latter difference is clearly large enough for the typical participant in an experiment (even in representative samples) to react. The overall lack of response indicates that many respondents find it difficult to incorprate the shift in their investment choice. In Section 5 we investigate in more detail to what extent different socioeconomic groups' investments react more elastically to incentives.

For now, returning to Table 3, we notice an important difference between the SOEP and the laboratory sample. While the SOEP participants appear to ignore the shifter on average, there is a strong and statistically significant reaction of investments to the treatment in the laboratory. There, the equity share rises from 0.3 to 0.63 in response to improving the return of the fund by 20 percentage points. This difference is highly statistically significant.

The beliefs about the fund's return, however, do not respond to the shifter in the way they should, no matter what measure of beliefs we use and no matter whether we consider the SOEP data or the laboratory data. While there is a statistically significant effect in the laboratory sample, it is way smaller than the 20 percentage points predicted by probabilistic sophistication, and there is no effect at all in the SOEP sample. In both samples and regardless of whether we consider imputed beliefs or stated beliefs, we can strongly reject the rational prediction that the shifter moves the mean of beliefs one-to-one.

We tentatively conclude from this evidence that it is much harder to manipulate beliefs than to elicit them. ${ }^{13}$ In light of the previous finding that subjects' investment choices strongly correlate with their elicited beliefs in the expected way, we still regard the elicited beliefs as meaningful predictors of choice. However, there are clear bounds as to how beliefs can be influenced. Whether this is due to cognitive limitations (which in our case amounts to the failure to perform a simple addition) or inherent in the process of belief formation is impossible to say with the available data. However, the next subsection will show that subjects' beliefs about past DAX returns are

\footnotetext{
${ }^{13}$ Incidentally, the absent correlation between shifter and beliefs prevents us from using the shifter as an instrument for beliefs. With probabilistic sophistication, we could have studied whether beliefs about returns are causal for investment choices - indeed, this was one of the reasons for our design — but as things are, we simply do not have a working first stage.
} 
surprisingly well adjusted.

\subsection{Calibration}
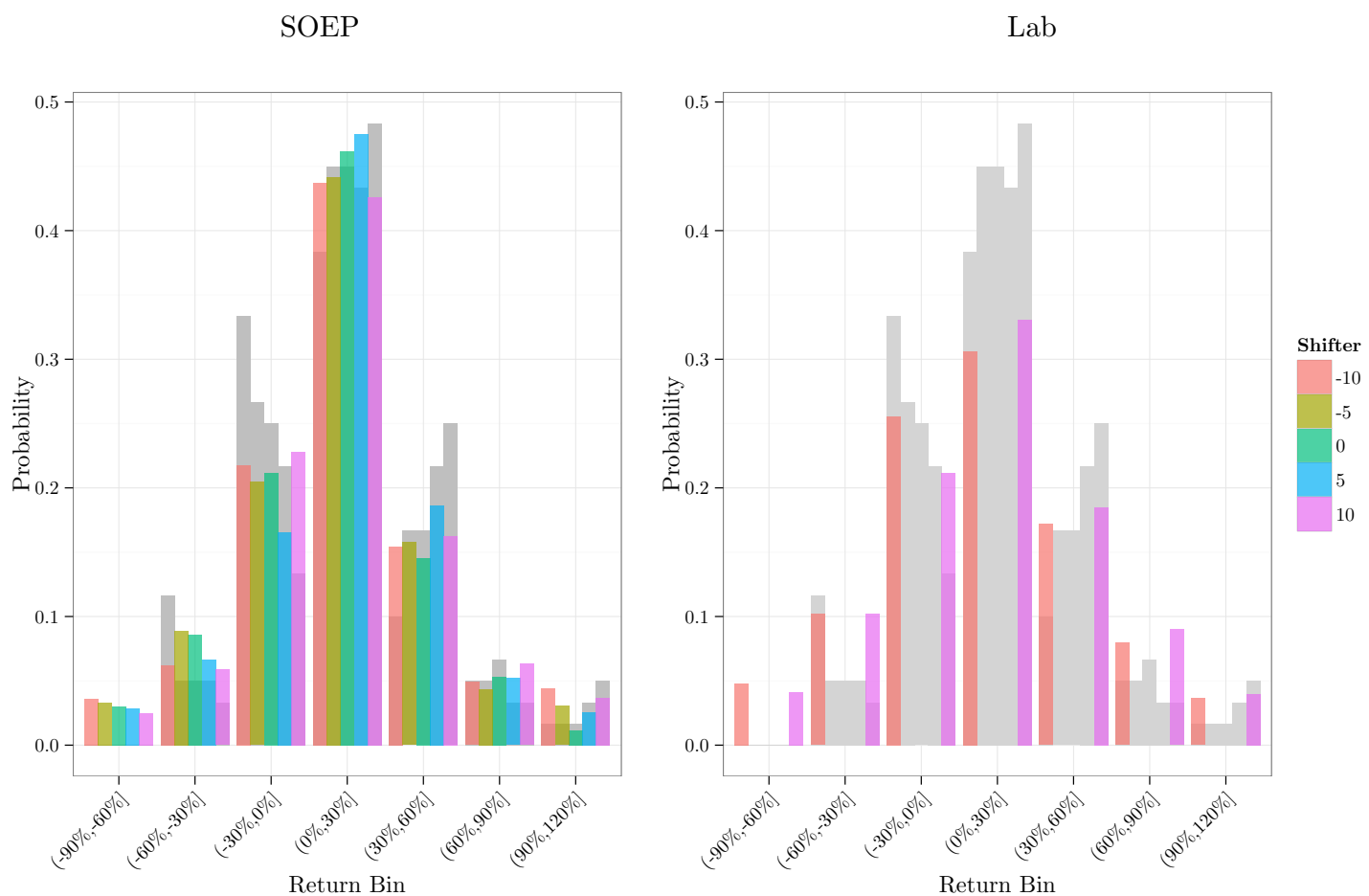

Historical benchmark for each treatment indicated by grey bars.

Figure 2: Historical distribution of returns vs. the average distributions in Lab and SOEP

Figure 2 compares the respondents' beliefs about the fund's return with the true historical distribution of DAX returns. The figure shows, in different colors and ordered from left to right within each bin, the five different distributions of beliefs for the five different treatments. The figure also compares these distributions with five corresponding true distributions, depicted in grey, that result from the true historical distribution plus the five shifters (in the same order, that is, from -10 to the very left to +10 to the very right). The figure shows that SOEP respondents are remarkably well calibrated. In none of the seven bins are respondents off by more than 5 percentage points when data are pooled across treatments. The largest deviations are that the frequency of small losses between 0 and $30 \%$ is slighly underestimated and the frequency of larger losses is slightly overestimated. The good calibration can also be seen in other metrics. While the mean return on the DAX from 1951 to 2010 was $15.5 \%$, both the imputed and the stated expected return on the experimental asset of $12.5 \%$ and $8.3 \%$ respectively - while lower - are still significantly above the assumed risk-free rate. Similarly, while the probability of a positive return over these six decades 
was $70.0 \%$, SOEP respondent thought the DAX had seen a gain $69.3 \%$ of the time. ${ }^{14}$ In contrast, the average distribution of our student subjects in the lab (also shown in Figure 2) differs significantly from the historical benchmark in that too much probability mass is assumed to be in the tails of the distribution.

That the return expectations we elicit show such remarkable calibration stands in contrast to evidence from other countries, where substantial miscalibration is commonly observed. For the US Kézdi and Willis (2009) report that HRS respondents expected a stock market gain with roughly $50 \%$ probability in the 2002, 2004 and 2006 waves while the historical probability of a gain on the Dow Jones was $68 \%$. Similarly, the probability of a gain larger than $10 \%$ was estimated at $39 \%$ but was really $49 \%$. Dominitz and Manski (2011) find similar numbers in monthly surveys in the monthly surveys of the Michigan Survey of Consumers from mid-2002 to mid-2004. In the Netherlands, M. Hurd et al. (2011) find that in 2004 the median expected rate of return was a mere $0.3 \%$, a severe underestimate of the historical median return of $14 \%$. Mis-calibration on the downside is by no means a universal finding, however. Respondents in the 1999, 2000 and 2001 waves of the Survey of Economic Expectations expected the S\&P 500 to go up with a probability ranging from $66.3 \%$ to $71.0 \%$ (Dominitz \& Manski, 2011).

What explains these differences with the existing literature? One possible explanation is that the papers quoted above compare respondents' expectations about the future with returns realized in the past. A test for correct calibration in this setting then amounts to a joint test of whether subjects hold the historical distribution of returns to be identical to the distribution of returns in the future and, if so, whether they have an accurate picture of the historical distribution. In contrast, we elicit beliefs about the distribution of returns over a well-defined period of time in the past and can test for calibration without auxilliary assumptions. The beliefs we elicit about the future, however, look fairly similar, if somewhat more pessimistic. The mean imputed return is $12.5 \%$ while the probability of a gain on the DAX is thought to be $58.8 \%$ on average. $51.8 \%$ of subjects state that they expect a return that is higher than $4 \%$.

Underneath this excellent calibration in the aggregate, however, lies subtantial heterogeneity in beliefs and miscalibration at the individual level. Very few of the distributions provided by individual respondents are close to the historical benchmark and what produces the excellent calibration in the aggregate is a mixture of respondents who put the entire probability mass into a single bin and respondents who report more diffuse distributions.

The fact that we elicit return expectations about both the past and the future also affords us an opportunity to test whether expectations change over time. As Figure 3 shows, they do indeed. Forward-looking expectations tend to be more negative than backward-looking expectations. SOEP respondents expect a return below zero to be significantly more likely to happen in the future than they think it has occurred in the past. In contrast to expectations about the past where SOEP respondents and students differed substatially (with the former being more realistic), we find virtually identical expectations about the future between the two samples.

\footnotetext{
${ }^{14}$ In order to predict whether subjects invest in the risky asset, a relevant question - under expected utility, the only relevant question - is whether respondents expect a strictly positive excess return, i.e. a mean return that exceeds $4 \%$. Based on reported beliefs, the proportion of respondents who expect a strictly positive excess return is $69.2 \%$ when using stated beliefs, and $72.6 \%$ when using imputed beliefs. The historical frequency of the DAX returning strictly more than $4 \%$ is $68.3 \%$.
} 

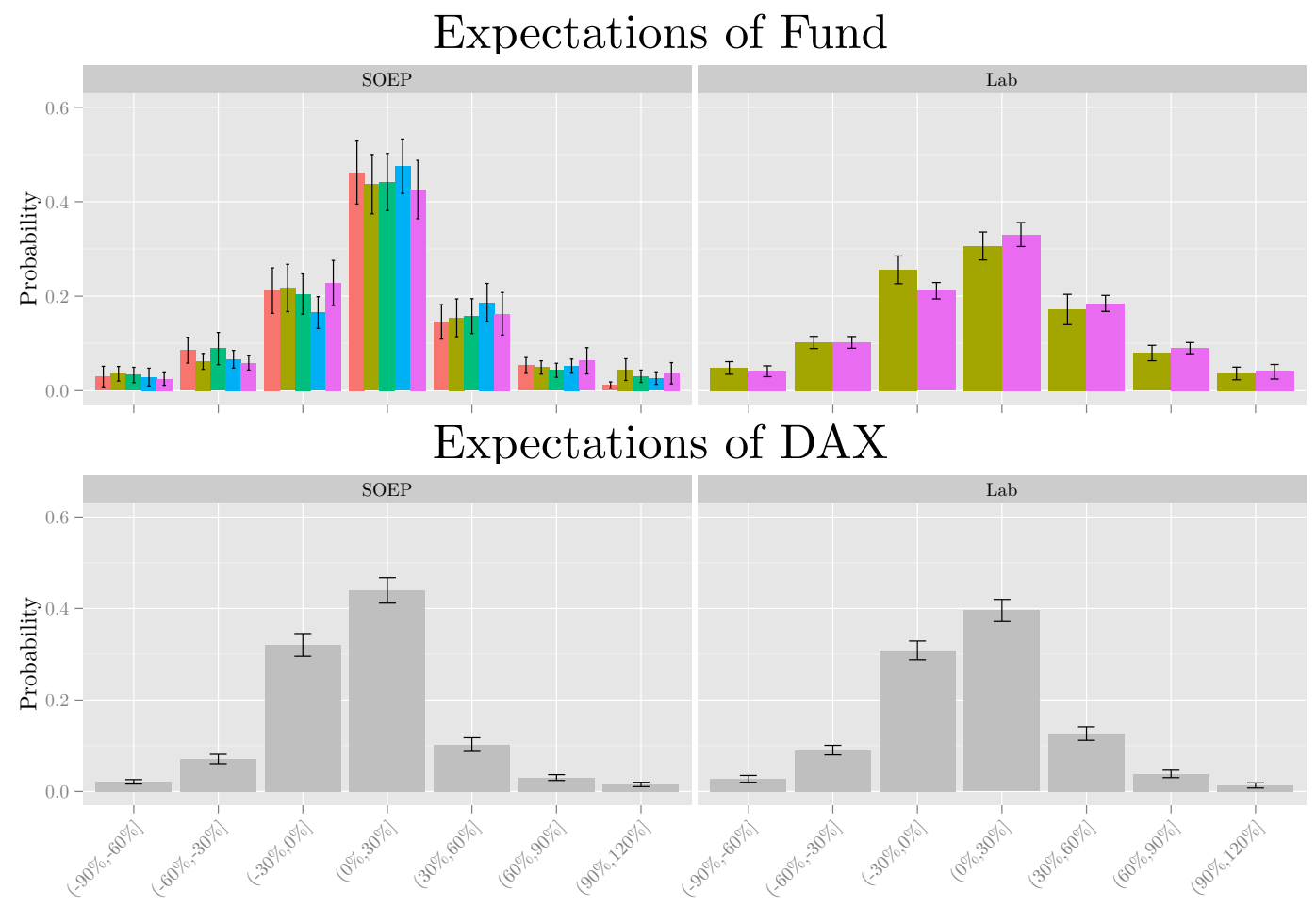

Figure 3: Average distributions about past and future

\section{External validity: Stock market participation}

We now turn to the important question whether our response variables are indicative of real-life investments. Specifically, we now test the external validity of our data by comparing elicited behavior in the experiment with survey responses to the question "Do you own any stock market mutual funds, stocks or reverse convertible bonds ("Aktienanleihe")?"

Table 4 shows that $18.0 \%$ of all households answered this question affirmatively, which is in line with other evidence on German stock market participation. ${ }^{15}$ The table also shows that for richer households the stock market participation increases but stays well below $100 \%$. As a measures of income and wealth, we split the sample by deciles of the income distribution (column 1) as well as by deciles of the distribution of earnings from interest, presumably our best available proxy for wealth. ${ }^{16}$

Figure 4 displays a correlogram, a visualization of the correlation matrix for several survey and experimental variables. Blue wedges indicate positive correlations, red wedges negative correlations.

\footnotetext{
${ }^{15}$ Most other surveys provide numbers only for the percentage of individuals who hold stock. In our data this percentage stands at 15.4\% (S.E.: 1.1\%) while a 2012 survey by Deutsches Aktieninstitut (2012) puts it at $13.7 \%$.

${ }^{16}$ The SOEP question about interest earned on investments over the previous year is answered by far more people than more detailed questions about the amounts of wealth held in the form of various assets. We therefore use this variable as a proxy for liquid wealth. The alternative measure, the sum over all asset classes, yields broadly similar though obviously less preciely estimated results. For details on these variables, see Appendix E.
} 


\begin{tabular}{ccc}
\hline & \multicolumn{2}{c}{ Stock Market Participation Rate by... } \\
Decile & Household Income & Liquid Wealth \\
\hline 1 & 6.67 & 0.00 \\
2 & 6.56 & 2.22 \\
3 & 3.28 & 1.96 \\
4 & 21.28 & 2.13 \\
5 & 13.68 & 5.36 \\
6 & 17.33 & 12.96 \\
7 & 20.00 & 10.64 \\
8 & 18.99 & 38.78 \\
9 & 25.86 & 43.14 \\
10 & 45.61 & 55.77 \\
\hline
\end{tabular}

Table 4: Stock-market participation rates by household income and liquid wealth deciles

Wedge size and hue are proportional to the strength of the correlations.

The correlogram shows that only a handful of variables are reliable predictors of stock market participation. Most of the significant correlations have been observed in the previous literature. For example, household size is known to be a significant correlate of stock market holdings. Household income, too, is a well-known and entirely unsurprising predictor of stock ownership. Notice that equity share is the only experimental variable that has predictive power for stock holdings (correlation: 0.14, p-value: <0.001).

But the correlograms only tell bivariate stories. We therefore investigate whether we can get the correlations to change if we add other explanatory variables. This is similar to the approach taken by Guiso et al. (2008) who study theco-variabtion of stock market participation with generalized trust and other variables. Indeed, we find that equity share has explanatory power over and above the other variables as shown in Table 5. Even after including all relevant controls, which drives up the $R^{2}$ to around $30 \%$, the coefficient for equity share remains both economically and statistically significant and is robust to different specifications.

The fact that equity share helps to explain stock holdings even if we control for all other variables that are known to be good predictors of stock market participation is important for two reasons. First, it establishes external validity. Investment behavior in the experiment is strongly related to investment behavior outside of the experiment. Second, the result gives hope that the simple experimental portfolio choice problem can be used as a wind tunnel. Regarding the specific exogenous manipulation that we employ, we observe that the experimental equity share responds at least for some participants to exogenous variations. While we cannot know whether similar exogenous changes in a real-world environment would generate similar responses, we still regard our evidence as supporting the claim that the experiment constitutes a useful testbed: it allows the controlled manipulation of a behavioral variable that has a close connection to stock market particpation, both in terms of economic theory and in terms of empirical correlation. 


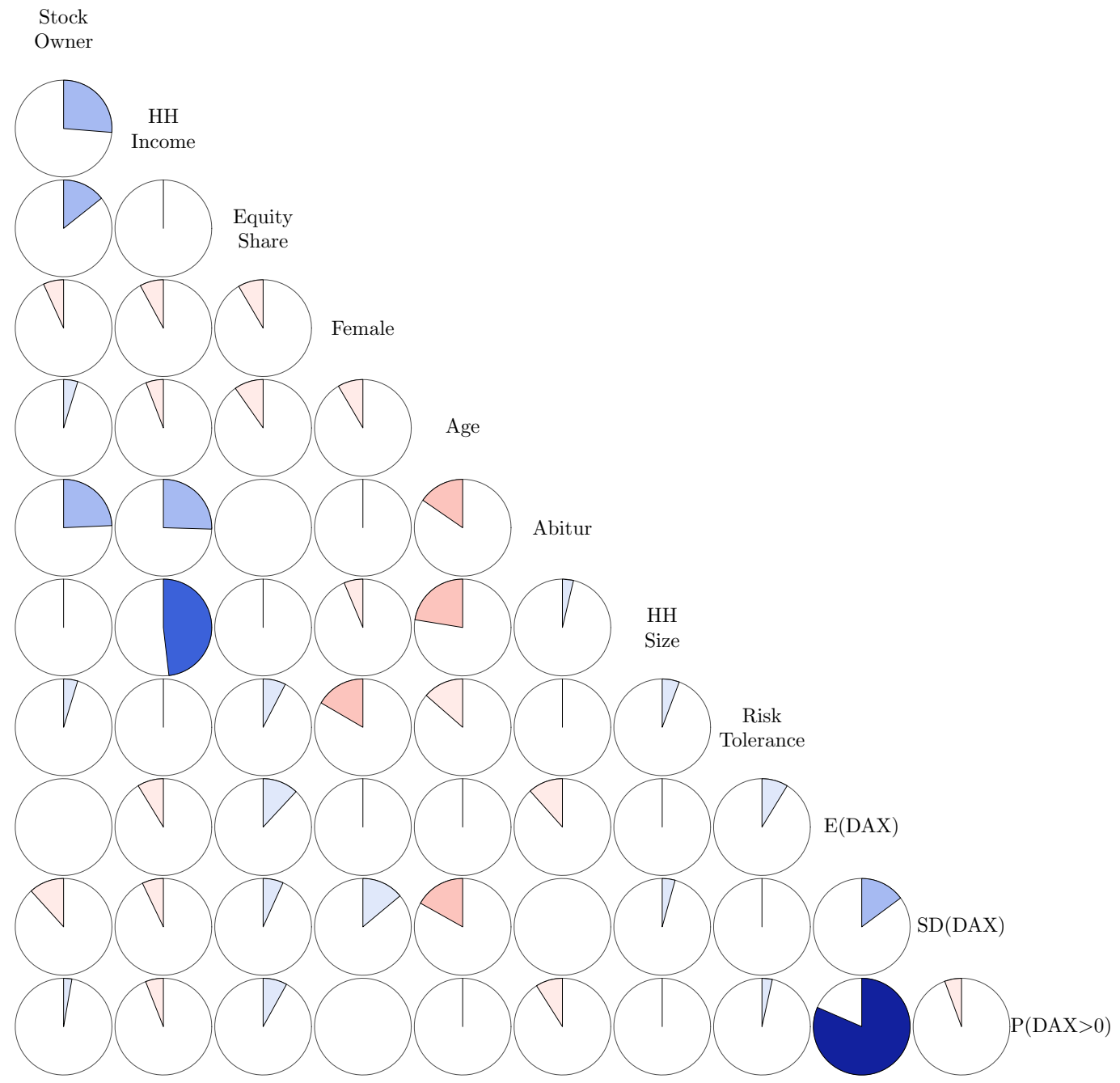

Figure 4: Correlogram 


\begin{tabular}{|c|c|c|c|}
\hline & \multicolumn{2}{|c|}{ Dependent variable: } & $\begin{array}{l}\text { : Stock Market Participant } \\
\text { (3) }\end{array}$ \\
\hline Equity Share & $\begin{array}{c}0.220^{* * *} \\
(0.072)\end{array}$ & $\begin{array}{c}0.240^{* * *} \\
(0.068)\end{array}$ & $\begin{array}{c}0.200^{* * *} \\
(0.064)\end{array}$ \\
\hline Female & & $\begin{array}{l}-0.043 \\
(0.032)\end{array}$ & $\begin{array}{l}-0.029 \\
(0.030)\end{array}$ \\
\hline Born in East Germany & & $\begin{array}{c}-0.058^{*} \\
(0.034)\end{array}$ & $\begin{array}{l}-0.044 \\
(0.033)\end{array}$ \\
\hline Age & & $\begin{array}{l}0.006 \\
(0.005)\end{array}$ & $\begin{array}{c}0.004 \\
(0.006)\end{array}$ \\
\hline $\mathrm{Age}^{2}$ & & $\begin{array}{l}-0.0001 \\
(0.0001)\end{array}$ & $\begin{array}{l}-0.0001 \\
(0.0001)\end{array}$ \\
\hline Abitur & & $\begin{array}{c}0.200^{* * *} \\
(0.061)\end{array}$ & $\begin{array}{l}0.150^{* *} \\
(0.058)\end{array}$ \\
\hline University Degree & & $\begin{array}{l}0.049 \\
(0.078)\end{array}$ & $\begin{array}{l}-0.003 \\
(0.072)\end{array}$ \\
\hline Household Size & & $\begin{array}{l}0.039^{* *} \\
(0.019)\end{array}$ & $\begin{array}{l}-0.004 \\
(0.022)\end{array}$ \\
\hline Risk Tolerance: Low & & $\begin{array}{c}0.020 \\
(0.037)\end{array}$ & $\begin{array}{c}0.034 \\
(0.035)\end{array}$ \\
\hline Risk Tolerance: High & & $\begin{array}{l}0.008 \\
(0.044)\end{array}$ & $\begin{array}{c}0.058 \\
(0.043)\end{array}$ \\
\hline Imputed expectation of DAX & & $\begin{array}{c}0.001 \\
(0.001)\end{array}$ & $\begin{array}{l}0.0003 \\
(0.001)\end{array}$ \\
\hline Imputed S.D. of DAX & & $\begin{array}{c}-0.003^{* * *} \\
(0.001)\end{array}$ & $\begin{array}{l}-0.001 \\
(0.001)\end{array}$ \\
\hline Gain Probability of DAX & & $\begin{array}{l}-0.003 \\
(0.088)\end{array}$ & $\begin{array}{c}0.039 \\
(0.085)\end{array}$ \\
\hline Number of Children in Household & & $\begin{array}{c}-0.096^{* * *} \\
(0.030)\end{array}$ & $\begin{array}{c}-0.057^{*} \\
(0.030)\end{array}$ \\
\hline Employed & & $\begin{array}{l}-0.015 \\
(0.036)\end{array}$ & $\begin{array}{l}-0.024 \\
(0.037)\end{array}$ \\
\hline Financially Literate & & $\begin{array}{c}0.140^{* * *} \\
(0.032)\end{array}$ & $\begin{array}{c}0.080^{* * *} \\
(0.031)\end{array}$ \\
\hline Interest: $<250$ Euros & & & $\begin{array}{l}0.061^{*} \\
(0.033)\end{array}$ \\
\hline Interest: 250 - 1.000 Euros & & & $\begin{array}{c}0.270^{* * *} \\
(0.057)\end{array}$ \\
\hline Interest: $1.000-2.500$ Euros & & & $\begin{array}{c}0.430^{* * *} \\
(0.086)\end{array}$ \\
\hline Interest: $>2.500$ Euros & & & $\begin{array}{c}0.310^{* * *} \\
(0.110)\end{array}$ \\
\hline Interest: refused to answer & & & $\begin{array}{c}0.150 \\
(0.100)\end{array}$ \\
\hline Household Income (missing $=0$ ) & & & $\begin{array}{c}0.023 \\
(0.018)\end{array}$ \\
\hline Household Income: missing & & & $\begin{array}{l}0.210^{* *} \\
(0.084)\end{array}$ \\
\hline Constant & $\begin{array}{c}0.110^{* * *} \\
(0.029)\end{array}$ & $\begin{array}{l}-0.130 \\
(0.140)\end{array}$ & $\begin{array}{l}-0.130 \\
(0.140)\end{array}$ \\
\hline $\mathrm{N}$ & 561 & 560 & 560 \\
\hline $\mathrm{R}^{2}$ & 0.021 & 0.150 & 0.280 \\
\hline Adjusted $\mathrm{R}^{2}$ & 0.019 & 0.130 & 0.250 \\
\hline
\end{tabular}

${ }^{*} \mathrm{p}<.1 ;{ }^{* *} \mathrm{p}<.05 ;{ }^{* * *} \mathrm{p}<.01$

Household income is in thousands of Euros

Table 5: Predicting real-world stock-market participation 


\section{Different results for different people}

In this section we exploit the rich data set on the SOEP respondents in order to study the role of socioeconomic background variables and direct measures or plausible correlates of savviness. As discussed above, we find strong differences between the SOEP sample and the university student sample regarding the extent to which they react to incentives. This raises the questions whether there is other evidence that "smart", financially savvy respondents react more strongly to variations in incentives. The subsequent analysis confirms the existence of such differences. They have potential implications for the consequences of interventions to foster household investments and policy changes may want to pay heed to the possibility that different households react differently to the variation of incentives. We also re-examine the issue of external validity and find that the link between experimental investments and stock market participation in real life is stronger for "smarter" respondents.

We caution that our examination of heterogeneity in the SOEP sample is a "fishing exercise" in the sense that we did not consider the effects of such heterogeneity in the design of the study (while, evidently, the statistical comparison between SOEP and lab participants was on our radar). However, the results of our fishing exercise are largely in line with what other studies have documented before, namely the fundamental role of cognitive ability for financial decisions making.

Table 7 documents treatment effects on choices and beliefs for different subgroups. It shows that there are small subsamples of the population that do react to better incentives. The coefficients indicate an increase in equity share of one percentage point per one percentage point increase in return. So, for respondents with a university degree, we find that moving from the worst shifter of -10 to the best shifter of +10 , the equity share is predicted to increase by 20 percentage points. This is similar to the effect we observed in the laboratory study with university students where the equity share increased by 33 percentage points. Hence, it appears that the main difference between SOEP and lab is driven by selection on educational covariates.

The results for different wealth levels are somewhat mixed. The strongest treatment effect is observed for those who withhold information on income from interest (for whatever reasons). There is also a notable composition effect between the two largest categories: Respondents with low but positive levels of income from interest are predicted to increase their equity share by 14 percentage points when we move from the worst to the best shifter. Those without any interest earnings are estimated to exhibit a negative treatment effect.

Among the financial literacy questions only the compound interest question is indicative of a positive treatment effect. The other variables that might capture financial literacy do not show significant interactions with the experimental treatment. While the results on financial literacy and wealth are a bit patchy, overall a picture emerges that is familiar from the literature. Even relatively simple investment tasks as the one we have implemented here appear to be cognitively so complex that sensible responses to variations in parameters are shown only by skilled and savvy subjects. An inspection of the two right columns of the table reveals that when it comes to belief manipulation no systematic patterns emerge. A single positive interaction between treatment and one of the financial literacy questions is countered by non-significance of university education and a negative effect of one of the other financial literacy questions.

Given that we can identify some subgroups that react better to incentives, it is not far-fetched to presume that we might also be able to detect a stronger external validity for these groups. With less noise in behavior inside and presumably outside the laboratory, the measured correlations between the experimental equity share and stock market participation may increase. Table 6 shows 
the regression-based conditional correlates of stock market participation, separately for different subgroups. Indeed it is the case that "smarter" subsamples show stronger external validity. 


\begin{tabular}{|c|c|c|c|c|}
\hline & \multicolumn{4}{|c|}{ Stock Market Participant } \\
\hline & All & Abitur & University Degree & Good Financial Literacy \\
\hline \multirow[t]{2}{*}{ Equity Share } & $0.200^{* * *}$ & $0.370^{* * *}$ & $0.480^{* *}$ & $0.230^{* *}$ \\
\hline & $(0.061)$ & $(0.140)$ & $(0.200)$ & $(0.097)$ \\
\hline \multirow[t]{2}{*}{ Female } & -0.029 & -0.120 & $-0.230^{* *}$ & -0.049 \\
\hline & $(0.029)$ & $(0.087)$ & $(0.110)$ & $(0.047)$ \\
\hline \multirow[t]{2}{*}{ Born in East Germany } & -0.044 & -0.021 & -0.160 & -0.083 \\
\hline & $(0.031)$ & $(0.091)$ & $(0.120)$ & $(0.054)$ \\
\hline \multirow[t]{2}{*}{ Age } & 0.004 & -0.028 & $-0.062^{* *}$ & 0.002 \\
\hline & $(0.005)$ & $(0.017)$ & $(0.026)$ & $(0.009)$ \\
\hline \multirow[t]{2}{*}{$\mathrm{Age}^{2}$} & -0.0001 & 0.0003 & $0.001^{* *}$ & -0.00004 \\
\hline & $(0.0001)$ & $(0.0002)$ & $(0.0003)$ & $(0.0001)$ \\
\hline \multirow[t]{2}{*}{ Abitur } & $0.150^{* * *}$ & & & $0.240^{* * *}$ \\
\hline & $(0.055)$ & & & $(0.091)$ \\
\hline \multirow[t]{2}{*}{ University Degree } & -0.003 & -0.002 & & -0.041 \\
\hline & $(0.068)$ & $(0.078)$ & & $(0.110)$ \\
\hline \multirow{2}{*}{ Household Size } & -0.004 & 0.036 & 0.045 & -0.020 \\
\hline & $(0.020)$ & $(0.067)$ & $(0.071)$ & $(0.031)$ \\
\hline \multirow[t]{2}{*}{ Risk Tolerance: Low } & 0.034 & -0.015 & -0.0003 & 0.048 \\
\hline & $(0.033)$ & $(0.088)$ & $(0.095)$ & $(0.054)$ \\
\hline \multirow[t]{2}{*}{ Risk Tolerance: High } & 0.058 & -0.002 & 0.098 & 0.058 \\
\hline & $(0.041)$ & $(0.130)$ & $(0.170)$ & $(0.058)$ \\
\hline \multirow[t]{2}{*}{ Imputed expectation of DAX } & 0.0003 & 0.002 & 0.001 & 0.001 \\
\hline & $(0.001)$ & $(0.005)$ & $(0.006)$ & $(0.002)$ \\
\hline \multirow[t]{2}{*}{ S.D. of DAX } & -0.001 & -0.002 & 0.002 & -0.001 \\
\hline & $(0.001)$ & $(0.003)$ & $(0.004)$ & $(0.002)$ \\
\hline \multirow[t]{2}{*}{ Gain Probability of DAX } & 0.039 & -0.051 & -0.330 & 0.062 \\
\hline & $(0.080)$ & $(0.240)$ & $(0.320)$ & $(0.140)$ \\
\hline \multirow[t]{2}{*}{ Number of Children in Household } & $-0.057^{* *}$ & -0.110 & $-0.180^{*}$ & -0.062 \\
\hline & $(0.028)$ & $(0.089)$ & $(0.100)$ & $(0.044)$ \\
\hline \multirow[t]{2}{*}{ Employed } & -0.024 & 0.033 & 0.022 & -0.007 \\
\hline & $(0.035)$ & $(0.092)$ & $(0.140)$ & $(0.061)$ \\
\hline \multirow[t]{2}{*}{ Financially Literate } & $0.080^{* * *}$ & $0.170^{* *}$ & $0.200^{* *}$ & \\
\hline & $(0.029)$ & $(0.086)$ & $(0.097)$ & \\
\hline \multirow[t]{2}{*}{ Interest: < 250 Euros } & $0.061^{*}$ & 0.047 & -0.033 & $0.086^{*}$ \\
\hline & $(0.032)$ & $(0.090)$ & $(0.120)$ & $(0.050)$ \\
\hline \multirow[t]{2}{*}{ Interest: 250 - 1.000 Euros } & $0.270^{* * *}$ & $0.330^{* * *}$ & $0.270^{*}$ & $0.320^{* * *}$ \\
\hline & $(0.055)$ & $(0.120)$ & $(0.150)$ & $(0.077)$ \\
\hline \multirow{2}{*}{ Interest: $1.000-2.500$ Euros } & $0.430^{* * *}$ & $0.560^{* * *}$ & $0.560^{* * *}$ & $0.440^{* * *}$ \\
\hline & $(0.081)$ & $(0.140)$ & $(0.160)$ & $(0.100)$ \\
\hline Interest: $>2.500$ Euros & $0.310^{* * *}$ & 0.150 & 0.013 & $0.560^{* * *}$ \\
\hline & $(0.100)$ & $(0.140)$ & $(0.180)$ & $(0.150)$ \\
\hline Interest: refused to answer & 0.150 & $0.350^{*}$ & 0.046 & $0.260^{*}$ \\
\hline & $(0.095)$ & $(0.180)$ & $(0.210)$ & $(0.140)$ \\
\hline Household Income (missing $=0$ ) & 0.023 & 0.039 & 0.029 & 0.010 \\
\hline & $(0.017)$ & $(0.032)$ & $(0.040)$ & $(0.026)$ \\
\hline Household Income: missing & $0.210^{* * *}$ & 0.150 & $0.520^{*}$ & 0.140 \\
\hline & $(0.078)$ & $(0.210)$ & $(0.290)$ & $(0.110)$ \\
\hline Constant & -0.130 & 0.580 & $1.400^{* * *}$ & -0.007 \\
\hline & $(0.140)$ & $(0.380)$ & $(0.550)$ & $(0.230)$ \\
\hline $\mathrm{N}$ & 560 & 122 & 72 & 283 \\
\hline $\mathrm{R}^{2}$ & 0.280 & 0.360 & 0.480 & 0.320 \\
\hline Adjusted $\mathrm{R}^{2}$ & 0.250 & 0.220 & 0.260 & 0.260 \\
\hline
\end{tabular}

${ }^{*} \mathrm{p}<.1 ;{ }^{* *} \mathrm{p}<.05 ;{ }^{* * *} \mathrm{p}<.01$

Table 6: Stock market participation by subgroups 


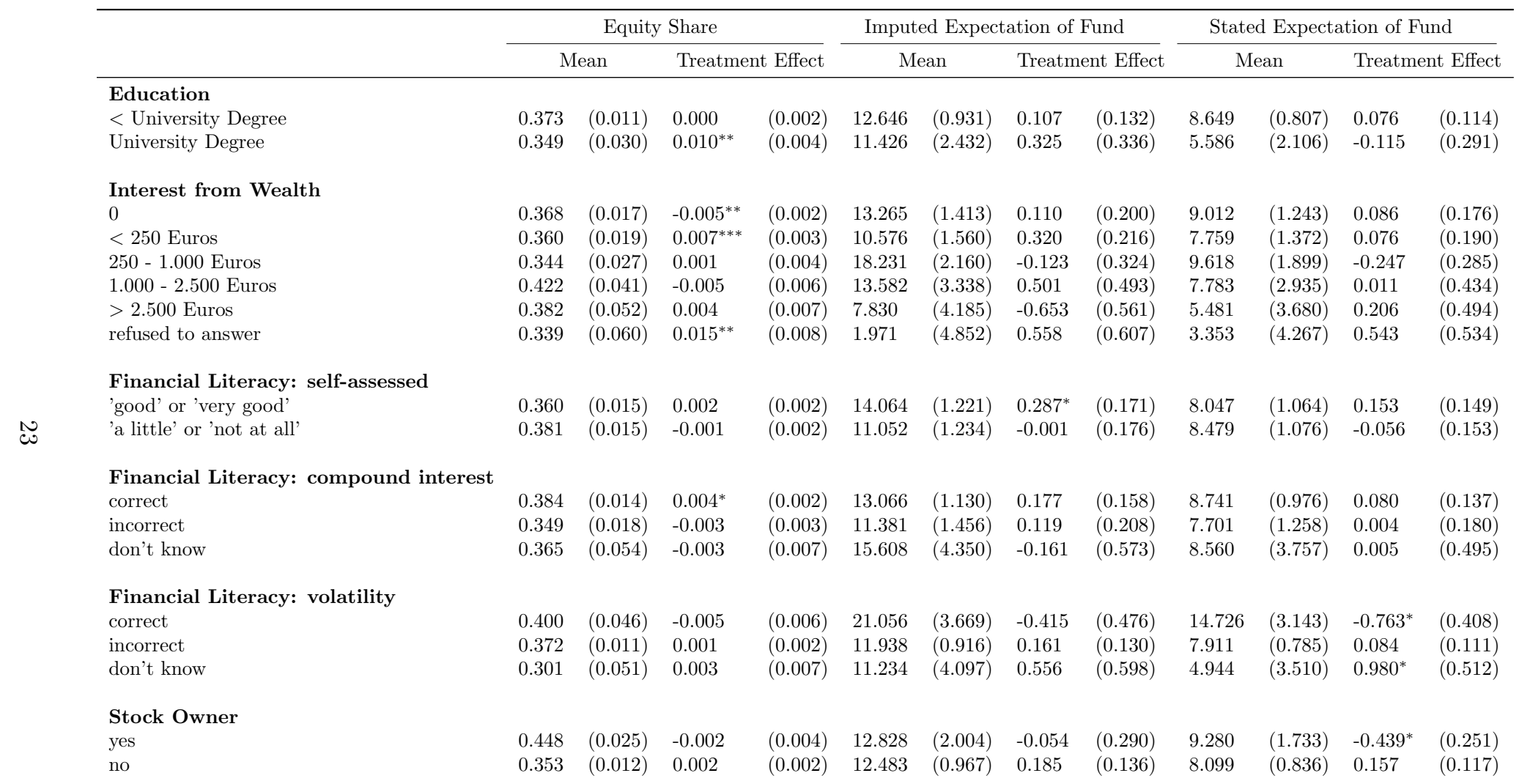

Table 7: Treatment effect by subgroups 


\section{Conclusion}

The paper describes an experiment on a simple portfolio choice model with one safe and one risky asset, implemented in an artefactual field experiment for a representative population sample in Germany. The data from this experiment exhibit high degrees of external validity as shown through direct comparison of behavior inside and outside the experiment. This is a success not only for the experiment but also for the model itself. Despite its extreme reductionism the model appears to capture important real-life tradeoffs in behavior in financial markets.

The analysis also shows that the degree of external validity (correlation between behavior inside and outside of the experiment) varies between different subgroups. External validity is stronger for skilled and savvy subjects.

We also observe that only these savvy subgroups of subjects respond in a meaningful way to changes in incentives, highlighting, once again, the important role of cognitive ability for even the simplest financial decision problems. In our setting less educated subjects forgo substantial additional earnings by not responding to exogenous incentives to invest into the risky asset. Related to previuos studies on financial literacy (e.g. Lusardi and Mitchell (2011) on retirment savings, Gerardi, Goette, and Meier (2010) on mortgage forclosure) this difference addresses the possibility of distributional effects that arise from cognitive differences. Related interventions on return manipulations in real life (such as tax subsidies for equity investments) could have similar undesired effects.

For future research, our study may inform the design of further wind tunnels for interventions regarding financial investment of households. In particular, in the light of the current underfunding of many pension systems (both pay as you go and capital funded) greater stock participation by the middle classes appears extremely desirable. Testing interventions in artefactual field experiments such as ours might avoid costly mistakes. 


\section{References}

Andersen, S., Harrison, G., Lau, M., \& Rutström, E. (2008). Eliciting Risk and Time Preferences. Econometrica, 76(3), 583-618. doi: 10.1111/j.1468-0262.2008.00848.x

Armantier, O., \& Treich, N. (2013). Eliciting Beliefs: Proper Scoring Rules, Incentives, Stakes and Hedging. European Economic Review, 62, 17-40. doi: 10.1016/j.euroecorev.2013.03.008

Arrondel, L., Calvo-Pardo, H., \& Tas, D. (2012). Subjective Return Expectations, Information and Stock Market Participation: Evidence from France. Retrieved from http://www.economics .soton.ac.uk/staff/calvo/documents/SubjectiveExpectations-16012012.pdf

Bellemare, C., Bissonnette, L., \& Kröger, S. (2012). Flexible Approximation of Subjective Expectations Using Probability Questions. Journal of Business E Economic Statistics, 30(1), 125-131. doi: 10.1198/jbes.2011.09053

Bertrand, M., Karlan, D., Mullainathan, S., Shafir, E., \& Zinman, J. (2010). What's Advertising Content Worth? Evidence from a Consumer Credit Marketing Field Experiment. Quarterly Journal of Economics(February), 263-306. doi: 10.1162/qjec.2010.125.1.263

Binswanger, J., \& Salm, M. (2013). Does Everyone Use Probabilities? Intuitive and Rational Decisions about Stockholding (IZA Discussion Papers No. 7265). Institute for the Study of Labor (IZA). Retrieved from http://ftp.iza.org/dp7265.pdf

Bucher-Koenen, T., \& Lusardi, A. (2011). Financial Literacy and Retirement Planning in Germany (Working Paper No. 17110). National Bureau of Economic Research. Retrieved from http:// www.nber.org/papers/w17110

Campbell, J. Y., \& Viceira, L. M. (2002). Strategic Asset Allocation: Portfolio Choice for Long-term Investors. New York: Oxford University Press.

Choi, S., Kariv, S., Müller, W., \& Silverman, D. (2013). Who Is (More) Rational? Retrieved from http://eml. berkeley.edu/ kariv/CKMS_I.pdf

Delavande, A., Giné, X., \& McKenzie, D. (2011). Eliciting Probabilistic Expectations with Visual Aids in Developing Countries: How Sensitive are Answers to Variations in Elicitation Design? Journal of Applied Econometrics, 497(January), 479-497. doi: 10.1002/jae.1233

Delavande, A., \& Rohwedder, S. (2008). Eliciting Subjective Probabilities in Internet Surveys. Public Opinion Quarterly, 72(5), 866-891. doi: 10.1093/poq/nfn062

Deutsches Aktieninstitut. (2012). Zahl der Aktienbesitzer geht wieder zurück (Tech. Rep.). Frankfurt am Main: Deutsches Aktieninstitut. Retrieved from https://www.dai.de/files/ dai_usercontent/dokumente/studien/2013-01_DAI-Kurzstudie_Aktionaerszahlen.pdf

Dohmen, T., Falk, A., Huffman, D., Sunde, U., Schupp, J., \& Wagner, G. G. (2011). Individual Risk Attitudes : Measurement, Determinants and Behavioral Consequences. Journal of the European Economic Association, 9(3), 522-550. doi: 10.1111/j.1542-4774.2011.01015.x

Dominitz, J., \& Manski, C. F. (2007). Expected Equity Returns and Portfolio Choice: Evidence from the Health and Retirement Study. Journal of the European Economic Association, 5(2-3), 369-379. doi: 10.1162/jeea.2007.5.2-3.369

Dominitz, J., \& Manski, C. F. (2011). Measuring and Interpreting Expectations of Equity Returns. Journal of Applied Econometrics, 26, 352-370. doi: 10.1002/jae.1225

Forsythe, G. E., Malcolm, M. A., \& Moler, C. B. (1977). Computer Methods for Mathematical Computations. Englewood Cliffs, NJ: Prentice-Hall.

Gerardi, K., Goette, L., \& Meier, S. (2010). Financial Literacy and Subprime Mortgage Delinquency: Evidence from a Survey Matched to Administrative Data (Vol. 10). Atlanta. Retrieved from http://www.frbatlanta.org/documents/pubs/wp/wp1010.pdf 
Goldstein, D. G., \& Rothschild, D. (2014). Lay Understanding of Probability Distributions. Judgment and Decision Making, 9(1), 1-14.

Greiner, B. (2004). The Online Recruitment System ORSEE 2.0 - A Guide for the Organization of Experiments in Economics. Retrieved from http://sourceforge.net/projects/orsee/ files/orsee-doc/2.0.2/orsee-doc-2.0.2.pdf

Grinblatt, M., Keloharju, M., \& Linnainmaa, J. (2011). IQ and Stock Market Participation. The Journal of Finance, 66 (6), 2121-2164. doi: 10.1111/j.1540-6261.2011.01701.x

Guiso, L., Sapienza, P., \& Zingales, L. (2008). Trusting the stock market. The Journal of Finance, 63(6), 2557-2600. doi: 10.1111/j.1540-6261.2008.01408.x

Haliassos, M., \& Bertaut, C. C. (1995). Why Do So Few Hold Stocks. The Economic Journal, 105 (September), 1110-1129.

Huck, S., \& Müller, W. (2012). Allais for all: Revisiting the Paradox in a Large Representative Sample. Journal of Risk and Uncertainty, 44(3), 261-293. doi: 10.1007/s11166-012-9142-8

Hurd, M., Rooij, M. V., \& Winter, J. (2011). Stock Market Expectations of Dutch Households. Journal of Applied Econometrics, 26, 416-436. doi: 10.1002/jae.1242

Hurd, M. D., \& Rohwedder, S. (2012). Stock Price Expectations and Stock Trading (Working Paper No. 17973). National Bureau of Economic Research. Retrieved from http://www.nber.org/ papers/w17973

Hyman, J. (1983). Accurate Monotonicity Preserving Cubic Interpolation. SIAM Journal on Scientific and Statistical Computing, 4(4), 645-654.

Karni, E., \& Safra, Z. (1995). The Impossibility of Experimental Elicitation of Subjective Probabilities. Theory and Decision, 38, 313-320.

Kézdi, G., \& Willis, R. J. (2009). Stock Market Expectations and Portfolio Choice of American Households. Retrieved from http://www.personal.ceu.hu/staff/Gabor_Kezdi/ WorkingPapers/Kezdi-Willis-July2009-complete.pdf

Lusardi, A., \& Mitchell, O. S. (2011). Financial Literacy and Planning: Implications for Retirement Wellbeing (Working Paper No. 17078). National Bureau of Economic Research. Retrieved from http://www.nber.org/papers/w17078

Merkle, C., \& Weber, M. (2014). Do Investors Put Their Money Where Their Mouth Is? Stock Market Expectations and Investing Behavior. Retrieved from http://papers.ssrn.com/ sol3/papers.cfm?abstract_id=1786456

Merton, R. (1969). Lifetime Portfolio Selection under Uncertainty: The Continuous-Time Case. Review of Economics and Statistics, 51(3), 247-257.

Naef, M., \& Schupp, J. (2009). Measuring Trust: Experiments and Surveys in Contrast and Combination (IZA Discussion Papers No. 4087). Institute for the Study of Labor (IZA). Retrieved from http://ftp.iza.org/dp4087.pdf

Rabin, M., \& Weizsäcker, G. (2009). Narrow Bracketing and Dominated Choices. American Economic Review, 99(4), 1508-1543. doi: 10.1257/aer.99.4.1508

Richter, D., \& Schupp, J. (2012). SOEP Innovation Sample (SOEP-IS) - Description and Structure of the SOEP Innovation Sample (Tech. Rep. No. 463). Berlin: DIW Berlin. Retrieved from https://www.diw.de/documents/publikationen/73/diw_01.c.407141.de/ diw_sp0463.pdf

Rothschild, D. (2012). Expectations: Point-Estimates, Probability Distributions, Confidence, and Forecasts. Retrieved from http://researchdmr.com/RothschildConfidence

Samuelson, P. (1969). Lifetime Portfolio Selection by Dynamic Stochastic Programming. Review of Economics and Statistics, 51(3), 239-246. 
Stehle, R., Huber, R., \& Maier, J. (1996). Rückberechnung des DAX für die Jahre 1955 bis 1987. Retrieved from http://edoc.hu-berlin.de/series/sfb-373-papers/1996-7/PDF/7.pdf

Stehle, R., Wulff, C., \& Richter, Y. (1999). Die Rendite deutscher Aktien in der Nachkriegszeit DAX-Rückberechnung für die Jahre 1948 bis 1955. Retrieved from http://www.econbiz.de/ archiv/b/hub/bank/rendite_blue-chip-aktien.pdf

Trautmann, S. T., \& van de Kuilen, G. (2011). Belief Elicitation A Horse Race Among Truth Serums. Retrieved from http://arno.uvt.nl/show. cgi?fid=120794

van Rooij, M., Lusardi, A., \& Alessie, R. (2007, October). Financial Literacy and Stock Market Participation (Working Paper No. 13565). National Bureau of Economic Research. Retrieved from http://www.nber.org/papers/w13565

Vissing-Jorgensen, A. (2004). Perspectives on Behavioral Finance: Does "Irrationality" Disappear with Wealth? Evidence from Expectations and Actions. NBER Macroeconomics Annual 2003, Volume 18, 18 (July).

von Gaudecker, H. M., van Soest, A., \& Wengström, E. (2011). Heterogeneity in Risky Choice Behavior in a Broad Population. The American Economic Review, 101 (April), 664-694. doi: http://dx.doi.org/10.1257/aer.101.2.664 


\section{Appendices}

\section{A Histogram Belief Elicitation Screen}

Markieren Sie jetzt bitte die 20 Kästchen so, dass Sie Ihre Einschätzung der Wertveränderung des Fonds widerspiegeln. Beachten Sie dabei alle für Sie denkbaren Möglichkeiten, die sich aus der historischen DAX-Entwicklung und dem Aufschlag von 10 Prozentpunkten ergeben.

Sollten Sie zu diesem Zeitpunkt Inre Investitionsentscheidung noch einmal ändern wollen, drücken Sie bitte auf "Zurück".

Füllen Sie die Kästchen immer, ohne Lücken, von UNTEN nach OBEN auf!

\begin{tabular}{|l|l|l|l|l|l|l|}
\hline & & & & & & \\
\hline & & & & & & \\
\hline & & & & & & \\
\hline & & & & & & \\
\hline & & & & & & \\
\hline & & & & & & \\
\hline & & & & & & \\
\hline & & & & & & \\
\hline & & & & & & \\
\hline & & & & & & \\
\hline & & & & & & \\
\hline & & & & & & \\
\hline & & & & & & \\
\hline & & & & & & \\
\hline & & & & & & \\
\hline & & & & & \\
\hline \\
\hline
\end{tabular}

Weiter

Figure A1: Belief elicitation screen 


\section{B Descriptive Statistics}

\begin{tabular}{|c|c|c|c|c|c|}
\hline Statistic & $\mathrm{N}$ & Mean & St. Dev. & Min & Max \\
\hline Female & 700 & 0.480 & 0.500 & 0 & 1 \\
\hline Age & 700 & 53.000 & 17.000 & 16 & 94 \\
\hline Born in Germany & 700 & 0.860 & 0.350 & 0 & 1 \\
\hline Born in the GDR & 700 & 0.200 & 0.400 & 0 & 1 \\
\hline Abitur & 700 & 0.200 & 0.400 & 0 & 1 \\
\hline University degree & 700 & 0.120 & 0.330 & 0 & 1 \\
\hline Employed & 700 & 0.500 & 0.500 & 0 & 1 \\
\hline Household Size & 700 & 2.300 & 1.200 & 1 & 8 \\
\hline Number of Children in Household & 700 & 0.360 & 0.780 & 0 & 6 \\
\hline Monthly Household Income (in 1000s of Euros) & 652 & 2.500 & 1.500 & 0.100 & 12.000 \\
\hline Risk Tolerance & 700 & 4.900 & 2.500 & 0 & 10 \\
\hline Financial Literacy (self-assessed: 'good' or 'very good') & 697 & 0.500 & 0.500 & 0 & 1 \\
\hline Financial Literacy (compound interest question correct) & 690 & 0.580 & 0.490 & 0 & 1 \\
\hline Financial Literacy (volatility question correct) & 690 & 0.840 & 0.370 & 0 & 1 \\
\hline Equity share (in experiment) & 562 & 0.370 & 0.260 & 0.000 & 1.000 \\
\hline Imputed expectation of fund & 562 & 13.000 & 21.000 & -80.000 & 110.000 \\
\hline Stated expectation of fund & 562 & 8.300 & 18.000 & -80.000 & 95.000 \\
\hline Gain Probability of Fund & 562 & 0.690 & 0.280 & 0.000 & 1.000 \\
\hline Imputed expectation of DAX & 562 & 5.500 & 18.000 & -60.000 & 90.000 \\
\hline Gain Probability of DAX & 562 & 0.590 & 0.330 & 0.000 & 1.000 \\
\hline Total Liquid Assets & 515 & 19.000 & 44.000 & 0.000 & 446.000 \\
\hline Stock Market Participation & 693 & 0.180 & 0.390 & 0 & 1 \\
\hline Stocks (amount) & 671 & $1,780.000$ & $7,874.000$ & 0 & 110,000 \\
\hline Stocks / Total Liquid Assets & 452 & 0.066 & 0.190 & 0.000 & 1.000 \\
\hline Total Debt & 666 & $17,174.000$ & $54,514.000$ & 0 & 800,000 \\
\hline
\end{tabular}

$N$ is the number of non-missing observations

Table A1: Descriptive statistics for the 700 heads of household in SOEP sample 
C Some Individual Belief Distributions

SOEP

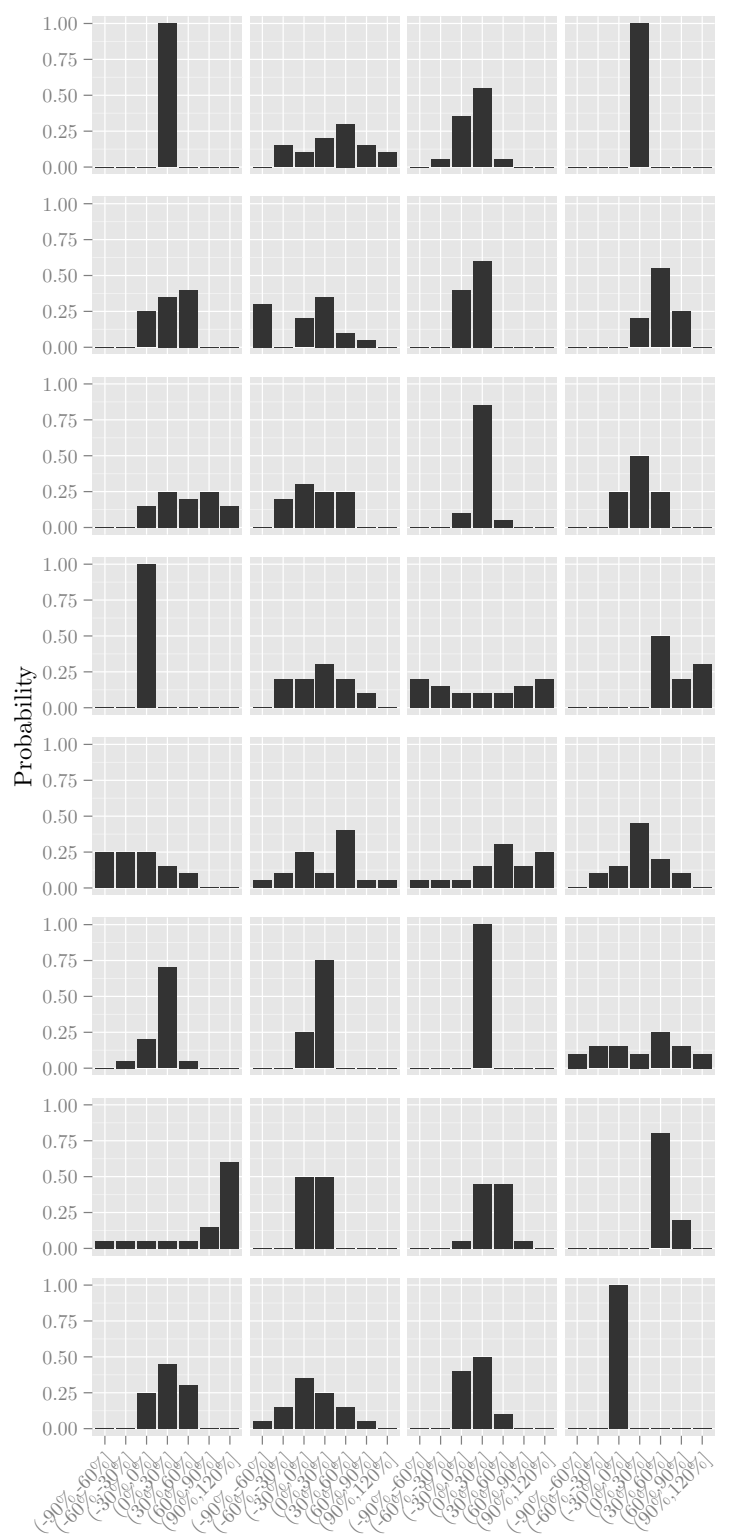

Return Bin
Lab

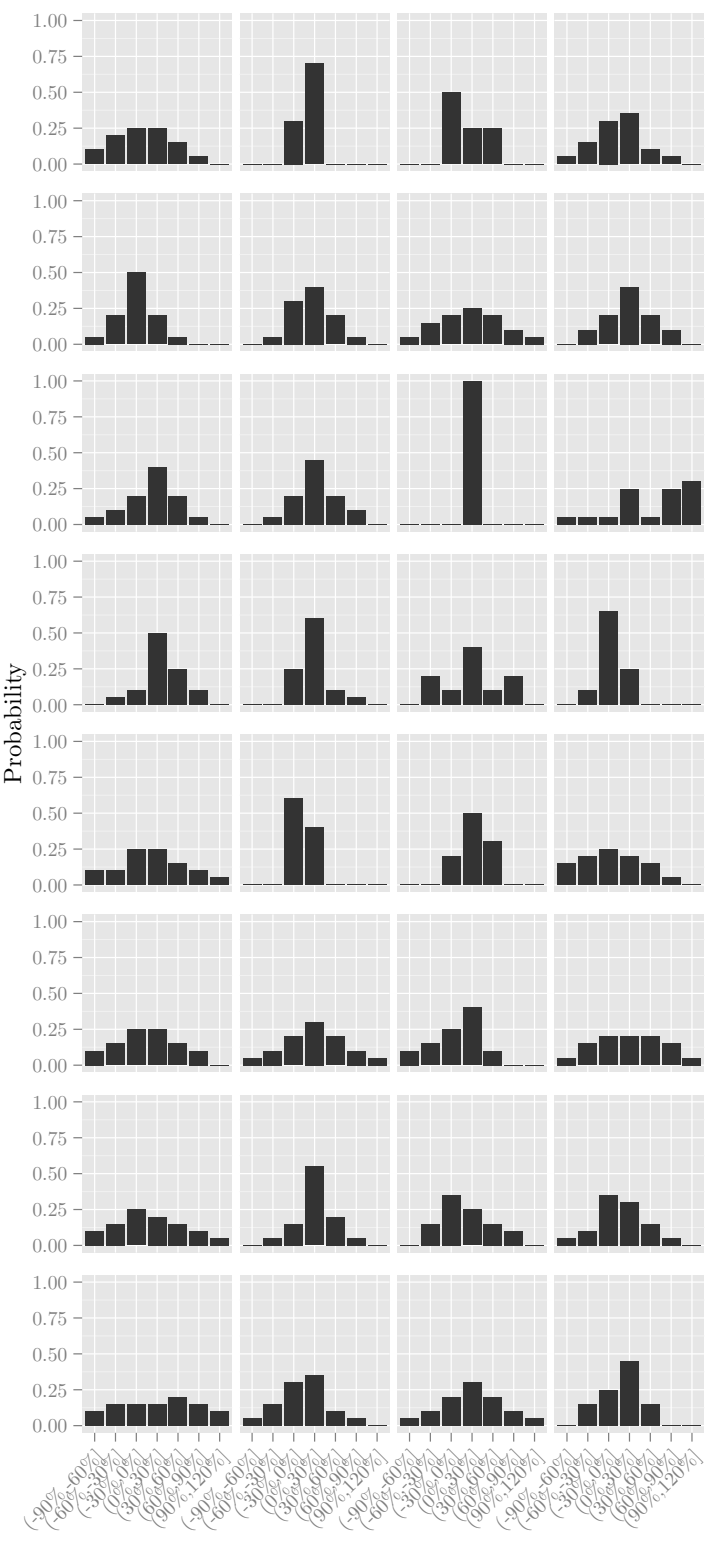

Return Bin 


\section{Imputation of Moments}

To derive various summary statistics from the elicited belief distributions we fit continuous distribution to the raw data and calculate the statistics from these distributions.

While much of the existing literature fits parametric distributions we follow an approach similar to Bellemare, Bissonnette, and Kröger (2012) and fit cubic interpolating splines using an approach due to Forsythe, Malcolm, and Moler (1977). We first cumulate the probabilities respondents place within each of the seven bins. This yields 8 points on the cumulative distribution function from which the responses were generated. We take these 8 points to be the knots of the spline (that is, we abstract from any rounding in the response and assume that the CDF at these points is known) and interpolate between them with a piecewise cubic polynomial.

Since each of the 7 pieces is defined by four polynomial coefficients this is a problem with 28 unknowns. The condition that the spline go through each of the 8 points gives 14 equations (one each for the end-points and two each for the interior knots) and further assuming that the spline is twice continuously differentiable at each of the knots yields 12 additional equations. What pins down the spline are two boundary conditions, which are found by fitting exact cubics through the four points closest to each boundary and imposing the third derivatives of these cubics at the end-points on the spline.

What's problematic about using such a spline to impute a CDF is that nothing in the procedure described above guarantees that the resulting spline is monotonic. To overcome this problem we therefore apply a filter to the spline that is due to Hyman (1983), which relaxes some of the smoothness conditions enough to ensure monotonicity. ${ }^{17}$

Figure A2 demonstrates the fit for a few representative respondents. Circles show the raw cumulative probabilities to which both the Hyman-filtered cubic splines as well as various alternative distributions are fitted. By construction the splines are extremely close to the data in all cases often much closer than any of the parametric distributions that have been fit to the data by minimizing the sum of squared deviations at the 8 points. The two distributions on the left are single-peaked and have non-zero probability in several bins and for these cases all of the methods yield roughly the same fit. The distributions in the middle have mass only in a single or in two of the bins, which is a problem for the parametric distributions because in such cases the fit can be improved ad infinitum by reducing the variance of the distribution and thereby reducing the sum of squared deviations at the 8 point. In the two cases on the right the distribution is multi-modal, which naturally leads to a terrible fit for the parametric distributions, which are all unimodal. The splines, in contrast make no such assumptions and therefore fit even these cases rather well.

Finally, we calculate both mean and standard deviation from these distributions numerically using adaptive Gauss-Kronrod quadrature.

\footnotetext{
${ }^{17}$ Both the Forsythe et al. construction of the spline as well as the Hyman filter are implemented in $\mathrm{R}$ through the splinefun() function with methods fmm and hyman respectively
} 

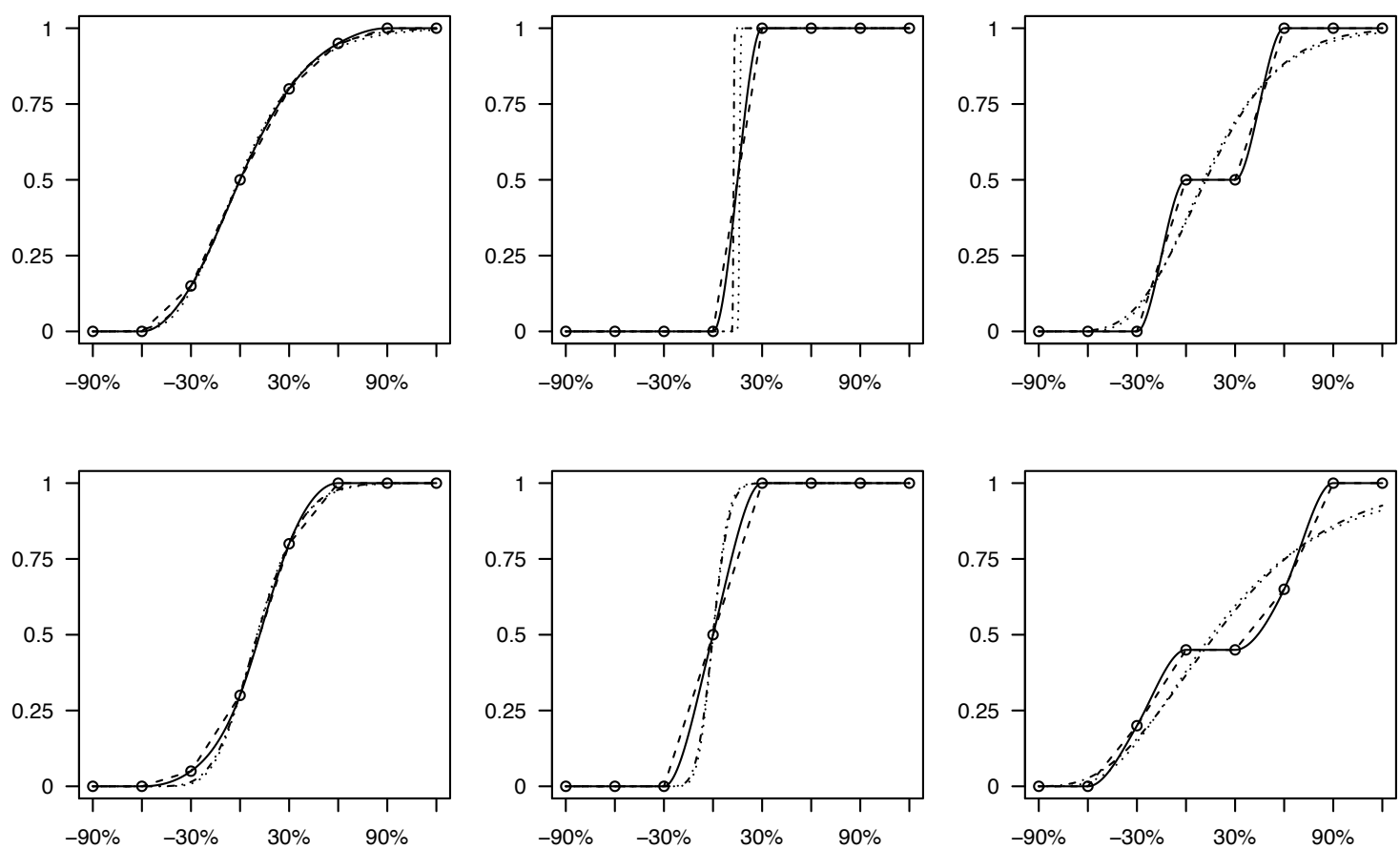

$$
\begin{array}{llll}
\text { _- Hyman-filtered cubic spline } & \ldots . . & \text { log-normal distribution } \\
& \text { linear spline } & . .- & \text { gamma distribution }
\end{array}
$$

Figure A2: CDFs derived from the belief data using both spline interpolation and parametric distributions fit via least squares 


\title{
E Variable Description and Coding
}

The full data set contains 1146 respondents in 700 households. Since asset allocation is commonly seen in the literature as the result of joint optimization of all household members we narrow the sample to the 700 heads of household, which we identify as the respondents who filled out the SOEP household questionnaire. All demographics whose coding is detailed below are the demographics of this household head.

\begin{abstract}
Abitur
Germany has a multi-track educational system in which only students who graduate from high school with an "Abitur" diploma are allowed to enroll at university. In the SOEP respondents are asked directly for the highest secondary school degree they have obtained and our Abitur variable is coded mainly according to the answer to this question. There is one special case, however, that requires special attention. 59 respondents obtained their secondary education outside of Germany and a separate question gives too little information to be able to map the secondary education they obtained into the German educational system precisely. Of these subjects, 11 have university degrees, however; education for which the Abitur is almost always a prerequisite. Since we are interested in the Abitur as a proxy for higher ability and higher education and foreign respondents with university degrees plausibly posess the same higher ability and higher education we recode these subjects as having Abitur.
\end{abstract}

\section{Born in East Germany}

This indicator variable is 1 if the respondent was born in the East German German Democratic Republic. It is 0 for respondents born in the West German Federal Republic of Germany, those born outside of Germany and those born in East Germany after reunification in 1990 (14 cases). This coding was chosen because we are not interested in whether a respondent was born in East Germany per se but in whether an education and socialization in a Socialist country has an effect.

\section{Interest from Wealth}

This variable is our main proxy for responents' liquid wealth holdings. Though our survey module included detailed questions about more specific asset classes, item non-response rates for the questions asking for the invested amounts were very high. The household questionnaire also included the question "How large, all in al, was your income from interest, dividend payments and capital gains in 2011"18. For the econometric analysis we generate a variable that uses information from both questions. We create a new category for subjects who report that their capital income was precisely zero, sort all respondents who gave exact answers into the six categories above and then merged the highest three categories into a single category for capital incomes above $€ 2500$ to increase the cell count (counts before the merge were 20 for the $€ 2500$ to $€ 5000$ category, 5 for the $€ 5000$ to $€ 10000$ category and 5 for the more than $€ 10000$ category. Lastly, we added a category for all subjects who refused to answer both questions.

\footnotetext{
${ }^{18}$ In German: "Wie hoch waren, alles in allem, die Einnahmen aus Zinsen, Dividenden und Gewinnen aus allen Ihren Wertanlagen im Jahr 2011?". Many respondents were either unwilling or unable to provide a precise answer to this question. In a follow-up question they were therefore asked to estimate the amount and choose between 6 categories: below $€ 250, € 250$ to $€ 1000, € 2500$ to $€ 5000$, $€ 5000$ to $€ 10000$, more than $€ 10000$
} 


\section{Financial Literacy}

We assess respondents' financial literacy in two different ways. First, we ask people to self-assess their financial literacy with the question:

"How knowledgable, all in all, are you in financial matters?"19

- very good

- good

- a little

- not at all

Second, we ask two questions that explicitly test respondents' financial literacy:

"Suppose you have $€ 100$ in a savings account. You receive $20 \%$ on this amount per year and leave the money in the account for 5 years. How much money will be in the account after these 5 years?" ${ }^{20}$.

- more than $€ 200$

- exactly $€ 200$

- less than €200

- don’t want to say

"What do you think? Which of the following types of investments has the largest fluctuations in returns over time?" 21 .

- savings accounts

- fixed income securities

- stocks

- don’t want to say

\section{Liquid assets}

All household members are asked about individual holdings of the following asset types:

1. checking accounts

2. savings accounts

3. call deposit accounts ("Tagesgeld")

4. fixed deposits

5. covered bonds, municipal bonds, bank bonds, corporate bonds or sovereign bonds

\footnotetext{
${ }^{19}$ In German: "Wie gut kennen Sie sich alles in allem in finanziellen Angelegenheiten aus? Gar nicht, ein bisschen, gut oder sehr gut?"

${ }^{20}$ In German: "Angenommen, Sie haben $100 €$ Guthaben auf Ihrem Sparkonto. Dieses Guthaben wird mit $20 \%$ pro Jahr verzinst, und Sie lassen es 5 Jahre auf diesem Konto. Wie viel Guthaben weist Ihr Sparkonto nach 5 Jahren auf?"

${ }^{21}$ In German: "Was glauben Sie: Welche der folgenden Anlageformen zeigt im Laufe der Zeit die höchsten Ertragsschwankungen? Sparbücher, festverzinsliche Wertpapiere oder Aktien?"
} 
6. stock market mutual funds, stocks or reverse convertible bonds ("Aktienanleihe")

7. real estate funds

8. bond and money market funds

9. other funds

10. other securities

For each of these types, respondents are first asked whether they own any assets of that type at all and, if the question is answered affirmatively, about the size of the asset holdings. Respondents are instructed to estimate this amount should they be unable to provide an exact figure. We code a household as participating in the stock market if the head of household answers the question about stock market mutual funds, individual stocks and reverse convertible bonds with "yes". 
F Robustness Checks 
F.1 Predicting real-world stock-market participation - alternative wealth measures, alternative specifications

\begin{tabular}{|c|c|c|c|c|c|c|}
\hline & \multicolumn{6}{|c|}{ Dependent Variable: Stock Market Participant } \\
\hline & OLS & OLS & OLS & OLS & OLS & Probit marginal effects \\
\hline & $(1)$ & $(2)$ & $(3)$ & $(4)$ & $(5)$ & $(6)$ \\
\hline Equity Share & $\begin{array}{c}0.220^{* * *} \\
(0.072)\end{array}$ & $\begin{array}{c}0.240^{* * *} \\
(0.068)\end{array}$ & $\begin{array}{c}0.200^{* * *} \\
(0.064)\end{array}$ & $\begin{array}{c}0.210^{* * *} \\
(0.066)\end{array}$ & $\begin{array}{l}0.140^{*} \\
(0.076)\end{array}$ & $\begin{array}{c}0.170^{* * *} \\
(0.056)\end{array}$ \\
\hline Female & & -0.043 & -0.029 & -0.028 & -0.028 & -0.016 \\
\hline \multirow[t]{2}{*}{ Born in East Germany } & & $-0.058^{*}$ & -0.044 & -0.032 & -0.021 & $-0.079^{* *}$ \\
\hline & & $(0.034)$ & $(0.033)$ & $(0.032)$ & $(0.036)$ & $(0.036)$ \\
\hline \multirow[t]{2}{*}{ Age } & & 0.006 & 0.004 & 0.002 & 0.006 & 0.003 \\
\hline & & $(0.005)$ & $(0.006)$ & $(0.005)$ & $(0.006)$ & $(0.006)$ \\
\hline \multirow[t]{2}{*}{$\mathrm{Age}^{2}$} & & -0.0001 & -0.0001 & -0.00004 & -0.0001 & 0.000 \\
\hline & & $(0.0001)$ & $(0.0001)$ & $(0.0001)$ & $(0.0001)$ & $(0.000)$ \\
\hline \multirow[t]{2}{*}{ Abitur } & & $0.200^{* * *}$ & $0.150^{* *}$ & $0.140^{* *}$ & $0.120^{*}$ & $0.140^{* * *}$ \\
\hline & & $(0.061)$ & $(0.058)$ & $(0.058)$ & $(0.065)$ & $(0.044)$ \\
\hline \multirow[t]{2}{*}{ University Degree } & & 0.049 & -0.003 & 0.013 & -0.014 & -0.021 \\
\hline & & $(0.078)$ & $(0.072)$ & $(0.074)$ & $(0.083)$ & $(0.052)$ \\
\hline \multirow[t]{2}{*}{ Household Size } & & $0.039^{* *}$ & -0.004 & 0.003 & 0.013 & 0.003 \\
\hline & & $(0.019)$ & $(0.022)$ & $(0.023)$ & $(0.028)$ & $(0.019)$ \\
\hline \multirow[t]{2}{*}{ Risk Tolerance: Low } & & 0.020 & 0.034 & 0.033 & 0.020 & 0.017 \\
\hline & & $(0.037)$ & $(0.035)$ & $(0.035)$ & $(0.039)$ & $(0.033)$ \\
\hline Risk Tolerance: High & & 0.008 & 0.058 & 0.052 & 0.058 & 0.068 \\
\hline & & $(0.044)$ & $(0.043)$ & $(0.043)$ & $(0.048)$ & $(0.042)$ \\
\hline Imputed expectation of DAX & & 0.001 & 0.0003 & 0.0005 & -0.0002 & 0.001 \\
\hline & & $(0.001)$ & $(0.001)$ & $(0.001)$ & $(0.001)$ & $(0.002)$ \\
\hline S.D. of DAX & & $-0.003^{* * *}$ & -0.001 & $-0.002^{* *}$ & -0.001 & $-0.002^{* *}$ \\
\hline & & $(0.001)$ & $(0.001)$ & $(0.001)$ & $(0.001)$ & $(0.001)$ \\
\hline Gain Probability of DAX & & -0.003 & 0.039 & 0.035 & 0.096 & 0.003 \\
\hline & & $(0.088)$ & $(0.085)$ & $(0.081)$ & $(0.096)$ & $(0.083)$ \\
\hline Number of Children in Household & & $-0.096^{* * *}$ & $-0.057^{*}$ & $-0.067^{* *}$ & $-0.072^{* *}$ & $-0.092^{* * *}$ \\
\hline & & $(0.030)$ & $(0.030)$ & $(0.031)$ & $(0.035)$ & $(0.031)$ \\
\hline Employed & & -0.015 & -0.024 & -0.030 & -0.006 & -0.015 \\
\hline & & $(0.036)$ & $(0.037)$ & $(0.037)$ & $(0.042)$ & $(0.039)$ \\
\hline Financially Literate & & $0.140^{* * *}$ & $0.080^{* * *}$ & $0.091^{* * *}$ & $0.078^{* *}$ & $0.071^{* *}$ \\
\hline & & $(0.032)$ & $(0.031)$ & $(0.032)$ & $(0.036)$ & $(0.030)$ \\
\hline Interest: $<250$ Euros & & & $0.061^{*}$ & & & $0.120^{* * *}$ \\
\hline & & & $(0.033)$ & & & $(0.046)$ \\
\hline Interest: $250-1.000$ Euros & & & $0.270^{* * *}$ & & & $0.260^{* * *}$ \\
\hline & & & $(0.057)$ & & & $(0.047)$ \\
\hline Interest: $1.000-2.500$ Euros & & & $0.430^{* * *}$ & & & $0.330^{* * *}$ \\
\hline & & & $(0.086)$ & & & $(0.058)$ \\
\hline Interest: > 2.500 Euros & & & $0.310^{* * *}$ & & & $0.270^{* * *}$ \\
\hline & & & $(0.110)$ & & & $(0.069)$ \\
\hline Interest: refused to answer & & & 0.150 & & & $0.170^{*}$ \\
\hline & & & $(0.100)$ & & & $(0.090)$ \\
\hline Total Liquid Assets (missing $=0$ ) & & & & $0.011^{* * *}$ & & \\
\hline & & & & $(0.003)$ & & \\
\hline Total Liquid Assets ${ }^{2}$ (missing $=0$ ) & & & & $-0.0001^{* *}$ & & \\
\hline & & & & $(0.00003)$ & & \\
\hline Total Liquid Assets ${ }^{3}$ (missing $=0$ ) & & & & 0.00000 & & \\
\hline & & & & $(0.00000)$ & & \\
\hline Total Liquid Assets: missing & & & & $0.130^{* * *}$ & & \\
\hline & & & & $(0.040)$ & & \\
\hline Household Income (missing $=0$ ) & & & 0.023 & $0.032^{*}$ & & $0.020^{*}$ \\
\hline & & & $(0.018)$ & $(0.017)$ & & $(0.012)$ \\
\hline Household Income: missing & & & $0.210^{* *}$ & $0.230^{* * *}$ & & $0.180^{* * *}$ \\
\hline & & & $(0.084)$ & $(0.082)$ & & $(0.069)$ \\
\hline Total Liquid Assets & & & & & $0.012^{* * *}$ & \\
\hline & & & & & $(0.003)$ & \\
\hline Total Liquid Assets ${ }^{2}$ & & & & & $-0.0001^{* *}$ & \\
\hline & & & & & $(0.00003)$ & \\
\hline Total Liquid Assets ${ }^{3}$ & & & & & 0.00000 & \\
\hline & & & & & $(0.00000)$ & \\
\hline Household Income & & & & & 0.020 & \\
\hline & & & & & $(0.019)$ & \\
\hline Constant & $0.110^{* * *}$ & -0.130 & -0.130 & -0.100 & -0.210 & \\
\hline & $(0.029)$ & $(0.140)$ & $(0.140)$ & $(0.130)$ & $(0.140)$ & \\
\hline $\mathrm{N}$ & 561 & 560 & 560 & 560 & 417 & 560 \\
\hline $\mathrm{R}^{2}$ & 0.021 & 0.150 & 0.280 & 0.290 & 0.310 & \\
\hline Adjusted $\mathrm{R}^{2}$ & 0.019 & 0.130 & 0.250 & 0.260 & 0.280 & \\
\hline Log Likelihood & & & & & & -187.000 \\
\hline AIC & & & & & & 422.000 \\
\hline
\end{tabular}

${ }^{*} \mathrm{p}<.1{ }^{* *} \mathrm{p}<.05 ;{ }^{* * *} \mathrm{p}<.01$

Income and Liquid assets are in thousands of Euros

Standard errors for OLS regressions are Huber-White heteroskedasticity-robust.

Standard errors for probit marginal effects are bootstrapped with 1000 replicates 